\title{
Slums from Space-15 Years of Slum Mapping Using Remote Sensing
}

\author{
Monika Kuffer ${ }^{1, *}$, Karin Pfeffer ${ }^{2}$ and Richard Sliuzas ${ }^{1}$ \\ 1 Faculty of Geo-Information Science and Earth Observation (ITC), University of Twente, PO Box 217, \\ 7500 AE Enschede, The Netherlands; r.sliuzas@utwente.nl \\ 2 Faculty of Social and Behavioural Sciences, University of Amsterdam, Nieuwe Achtergracht 166, \\ 1018 WV Amsterdam, The Netherlands; k.pfeffer@uva.nl \\ * Correspondence: m.kuffer@utwente.nl; Tel.: +31-53-4874301
}

Academic Editors: Ioannis Gitas and Prasad S. Thenkabail

Received: 6 April 2016; Accepted: 18 May 2016; Published: 27 May 2016

\begin{abstract}
The body of scientific literature on slum mapping employing remote sensing methods has increased since the availability of more very-high-resolution (VHR) sensors. This improves the ability to produce information for pro-poor policy development and to build methods capable of supporting systematic global slum monitoring required for international policy development such as the Sustainable Development Goals. This review provides an overview of slum mapping-related remote sensing publications over the period of 2000-2015 regarding four dimensions: contextual factors, physical slum characteristics, data and requirements, and slum extraction methods. The review has shown the following results. First, our contextual knowledge on the diversity of slums across the globe is limited, and slum dynamics are not well captured. Second, a more systematic exploration of physical slum characteristics is required for the development of robust image-based proxies. Third, although the latest commercial sensor technologies provide image data of less than $0.5 \mathrm{~m}$ spatial resolution, thereby improving object recognition in slums, the complex and diverse morphology of slums makes extraction through standard methods difficult. Fourth, successful approaches show diversity in terms of extracted information levels (area or object based), implemented indicator sets (single or large sets) and methods employed (e.g., object-based image analysis (OBIA) or machine learning). In the context of a global slum inventory, texture-based methods show good robustness across cities and imagery. Machine-learning algorithms have the highest reported accuracies and allow working with large indicator sets in a computationally efficient manner, while the upscaling of pixel-level information requires further research. For local slum mapping, OBIA approaches show good capabilities of extracting both area- and object-based information. Ultimately, establishing a more systematic relationship between higher-level image elements and slum characteristics is essential to train algorithms able to analyze variations in slum morphologies to facilitate global slum monitoring.
\end{abstract}

Keywords: slums; informal areas; urban remote sensing; Global South; VHR imagery

\section{Global Urbanization and Slum Dynamics: The Context}

Currently, about one-quarter of the world's urban population lives in slums, which are defined by UN-Habitat as informal settlements [1] or areas deprived of access to safe water, acceptable sanitation, and durable housing; in addition to being areas that are overcrowded and lack land tenure security [2]. Over the last 15 years, there has been renewed interest in slum improvement and eradication by local and international organizations dealing with development issues. During this period, slums became a more prominent subject of remote sensing (RS) image analysis. Supported by increased availability of very-high-resolution (VHR) data and methodological advances, many RS studies [3-8] aimed to produce information on the geography and dynamics of slums. Thus a multiplicity of images, concepts, 
algorithms and applications have become available. However, to upscale the existing knowledge and set the stage for innovations, a systematic review of what works in which context is still lacking. This article fills this gap by reviewing recent and contemporary approaches, indicators, data sources, and lessons learned from empirical cases with respect to physical slum characteristics that could form a basis for a systematic global slum inventory. Before doing so, we first introduce some aspects of slum development in the Global South (the term Global South is commonly used in the field of development studies and refers to developing countries, mainly located in the Southern Hemisphere; Global North on the other hand refers to developed countries [9]).

Slum-identification studies are very much driven by the persistence and growth of slums and emergence of new slums being inexorably part of contemporary urbanization processes, particularly in the Global South where rapid slum development is linked to the failure of formal land markets and low planning capacity. For example, the city of Hyderabad, India experienced a 70\% increase of slum areas between 2003 and 2010 [10], a situation that is by no means unique [11]. A recent UN-Habitat report [12] stated that the urban population in Sub-Saharan Africa (SSA) is growing by 10 million people annually, of which 7 million are likely to move into slums. Latest estimates by UN-Habitat [1] suggest that, in Africa, $62 \%$ of the urban population is living in slums; in Asia, it is up to $30 \%$; and in Latin America and the Caribbean, the rates of living in slums is $24 \%$. Over the last six to seven decades, various policy discourses and programs addressing slums have emerged. During the 1950s and $60^{\prime}$ s, slum settlements were often tolerated or neglected as "traditional villages." As large-scale evictions were found to be ineffective due to their impact on the livelihoods of dwellers $[13,14]$, in situ slum upgrading [13], and low-cost housing solutions such as site and service schemes and guided land development emerged $[15,16]$. Resettlement programs often further contributed to impoverishment [17], though some successful resettlement projects [18] showed that long-term community empowerment programs are necessary to ensure lasting improvements [19] that may also take several generations to materialize [20]. By contrast, in situ upgrading programs showed success in many places [21]. Since the 90 's, the global slum debate centered very much on ensuring land tenure security $[2,22]$, and slum upgrading is once more strongly favored above forced displacement. Presently, many local governments do not fully "acknowledge the existence of slums and informal settlements" ([1], p. 5), as available "data is often ad hoc and not connected to robust city-wide monitoring and evaluation processes" ([1], p. 5). In support of such local and global information needs for the development of pro-poor policies, innovative methods are required to enhance our understanding of the spatial and temporal dynamics of slums towards the creation of knowledge repositories on slums. For the development of such repositories, reliable and robust slum-detection methods are required that would allow for a global comparison but also provide support to less resourced countries and cities (e.g., allowing local adaptations of indicators in form of "slider widgets and/or buttons in a graphical user interface (GUI)" ([23], p. 321). Such repositories can form a basis for socioeconomic data integration [24] and offer essential information for "devising and implementing customized approaches of slum upgrading" ([25], p. 276). Moreover, consistent global coverage of slum data is required for international policy development and urban agenda setting at national levels. UN-Habitat facilitates this process and produces global statistics on slum development and distribution that are disseminated via its State of the World Cities reports $[26,27]$ and other publications, but its efforts have delivered estimates of slum dwellers rather than maps of slum extents, which would provide a much-needed picture of the changing locations, extents and densities of slums.

\section{The Utility of Remote Sensing for Slum Mapping}

In many cities, slums are a major part of the urban housing stock and an important part of the urban economy. It is important to realize that "slums disappear not through being removed, but by being transformed" ([28], p. 1). However, we lack information about slums, specifically their scale, location, extent, boundaries, populations, buildings and enterprises [29]. Consequently, holistic strategies [22] that focus on understanding the local role of slums, the needs of their inhabitants, 
as well as their geography and spatial dynamics are required. Remote sensing can play a key role in analyzing "space-time dynamics" [30], such as monitoring densification and expansion processes or assisting in the implementation of slum improvement policies. Furthermore, it allows linking the urban morphology with socioeconomic parameters [31]. Remote sensing is capable of mapping the amount of slums in highly hazardous areas or the general environmental conditions [32] that play an important role for urban health campaigns $[29,33]$. The utility of slum mapping has been stressed by Slum/Shack Dwellers International (SDI), e.g., maps are an important historic archive in court cases protecting dwellers against unlawful evictions [34]. In support of pro-poor policy formulation, it is important to combine such spatial information with community-driven mapping to understand local needs [29,35].

Spatiotemporal information on slums is scarce at the city scale, while regional or global knowledge will not be realized without utilizing RS techniques that allow for frequent coverage of large areas. However, deriving this information from RS imagery is not a straightforward process involving multiple choices as it can be done in many ways. A first attempt in bringing together the methodological expertise on slum mapping and monitoring was an expert meeting in 2008 [36] with the aim to review potential, limitations and methods for slum identification based on VHR imagery that included: (a) visual interpretation; (b) object-based image analysis (OBIA); (c) texture-based methods; and (d) community-based approaches. One of the identified challenges was that slum conditions can take various forms and, therefore, no universal model of slums existed. This is due to differences in slum-development processes [37], their age and thus developmental stages (infancy, consolidation, maturity), geographical location and context (e.g., central versus peri-urban [38] or arid versus tropical coastal cities [39]). Hence, the diversity of urban slums and geographic contexts requires methodological adjustments. Another identified challenge was the "level (scale) of analysis," specifically object-based [40] versus area-based identification of slums [41]. While object-based analysis concerns the extraction of urban objects such as slum roofs, area-based refers to the extraction of homogeneous urban patches (HUP) [42], also called "analytical regions" [43] representing slum neighborhoods. Since 2008, many studies have addressed some of these challenges. For instance, a slum ontology was developed [5,7] to conceptualize the spatial characteristics of slums for OBIA. Researchers applying several auxiliary methods (e.g., machine learning [44], statistical methods [6], and image texture [45]) have improved the potential for slum identification. The use of large indicator sets $[6,46]$ has improved slum-identification accuracies.

The key role of remote sensing for slum detection was stressed in recent reviews on urban analysis via RS applications [30,47,48]. However, neither review focused on the plurality of methods and their relevance for slum detection. Therefore, this review presents the methodological and technological advances in slum-identification methods and employed indicator sets that have emerged over the last 15 years. In doing so, we identify RS imagery, methods and indicators relevant for a global slum inventory in support of pro-poor policy implementations. The structure of the review is as follows: Section 3 provides an overview of the employed methodology, followed by contextual factors, such as terminology, purposes and mapped slum locations in Section 4. Section 5 discusses physical slum characteristics and their diversity. Section 6 reviews data and requirements of slum studies. Section 7 reviews employed methods, while the eighth section discusses the most promising aspects for the development of a global slum inventory. In the final section, we draw conclusions on the feasibility of a global knowledge repository on slums.

\section{Methodology of Review}

Exploring potential and limitations of slum-identification methods based on RS imagery has received increasing attention amongst RS experts. Although the underlying drivers for this rise in interest is not exactly clear, it has been stimulated by growing international motivation to reduce the numbers of slum dwellers that has created a demand for policy-relevant information [1]. Furthermore, it has been stimulated by the widespread access to VHR satellite images and advances in geospatial technologies that has essentially democratized space imagery and spatial mapping, accompanied by a 
growing number of algorithms for detecting and classifying urban areas, including slums. However, the two main initiatives to generate a global up-to-date geo-database on the "location, shape, and dynamics of built-up areas" ([49], p. 905), specifically the Global Human Settlement Layer (GHSL) (using optical data) and the Global Urban Footprint (GUF) layer (using SAR data) [50,51], stressed the difficulties of detecting the more organic patterns of slums [52]. Both initiatives focus on built-up areas and not specifically on slum mapping. Reasons for low identification accuracies of slums are attributed to their rather different morphological characteristics [53] (e.g., higher roof coverage densities, more organic patterns, and small building sizes) compared to formal built-up areas (Table 1). This methodological challenge has contributed to the large diversity in slum-mapping approaches and employed image-based proxies.

Table 1. Morphological features typical for slum areas (adapted from $[41,54]$ ).

\begin{tabular}{lllll}
\hline Features & \multicolumn{2}{l}{ Slum Areas } & \multicolumn{2}{l}{ Formal Built-Up Areas } \\
\hline Size & $\bullet$ & Small (substandard) building sizes & $\bullet$ & Generally larger building sizes \\
\hline Density & $\bullet$ & $\begin{array}{l}\text { (Very) high roof coverage densities } \\
\text { Lack of public (green) spaces within or } \\
\text { in the vicinity of slum areas }\end{array}$ & $\bullet$ & $\begin{array}{l}\text { Low to moderate density areas } \\
\text { Provision of public (green spaces) } \\
\text { within or in vicinity of planned areas }\end{array}$ \\
\hline Pattern & $\bullet$ & $\begin{array}{l}\text { Organic layout structure (no orderly } \\
\text { road arrangement and noncompliance } \\
\text { with set-back standards) }\end{array}$ & $\bullet$ & $\begin{array}{l}\text { Regular layout pattern (showing } \\
\text { planned regular roads and } \\
\text { compliance with set-back rules) }\end{array}$ \\
\hline Site Characteristics & $\bullet$ & $\begin{array}{l}\text { Often at hazardous locations (e.g., } \\
\text { flood prone, close to industrial areas, } \\
\text { steep slope) } \\
\text { Proximity to infrastructure lines and } \\
\text { livelihood opportunities }\end{array}$ & $\bullet$ & $\begin{array}{l}\text { Land has basic suitability for being } \\
\text { built-up } \\
\text { (Basic) infrastructure is provided }\end{array}$ \\
\hline
\end{tabular}

This review analyzes the diversity of RS studies of the past 15 years that deal with the challenge of extracting slums. It is based on a systematic literature search, performed in December 2015, using several search engines (Web of Science, Science Direct, SpringerLink Journals, Taylor \& Francis and Scopus) and covers the keywords "slums," "informal," "unplanned," "squatter," "precarious," "spontaneous," "illegal," "deprived," "irregular" or "substandard settlement/area," "self-help housing," "shantytown," "favela" or "bidonville" and "mapping" or "remote sensing." The review covers journal publications, book sections and conference publications that could be retrieved either via the employed research engines or websites of the main RS conferences. Only English-language papers are selected, and very similar publications by the same authors (e.g., journal and conference publication) were counted only once. In total, 87 key publications ([3-7,10,23,25,31-33,38-41,43-46,54-121]) are identified. A temporal analysis of the number of publications shows an increasing trend (Figure 1), having a high linear correlation with the number of satellite launches $\left(r^{2}=0.75\right)$. Satellite launches were derived from the following websites (including only the earth observation satellites with a spatial resolution of $5 \mathrm{~m}$ and less):

- ITC's database of Satellites and Sensors: http://www.itc.nl/research/products/sensordb/ searchsat.aspx

- Gunter's Space Page: http://space.skyrocket.de/directories/chronology.htm

- Satellite on the Net: http://www.satelliteonthenet.co.uk/index.php/launch-schedule

In the mid-2000s, when more VHR satellites became available the number of related publications increased. The same occurred for the period after 2010.

The analytical framework (Figure 2) for analyzing the retrieved publications, inspired by the outcome of the expert meeting on slum mapping [36], forms the skeleton for this review. Figure 2 shows that slum formation and development in global cities are impacted by several contextual factors, 
such as geographic location and climate, the topography of the city, the location within the city including proximity to services, and general socioeconomic and political factors (e.g., land governance). For example, slum dwellers often trade off accessibility to livelihood opportunities with locations exposed to hazards. Physical slum characteristics are often an expression of the slum-development processes: i.e., from low-density at their infancy stage to high-density mature slums, sometimes also including increasing building size and height. For example, slums can have multiple incrementally constructed floors [2]. Patterns of roads, building layouts and general site characteristics define the growth potential of a specific settlement. When mapping slums, physical slum characteristics need to be well understood for translating them into image-based proxies. The data and requirements of slum-mapping studies relate to imagery and ancillary data and the level (scale) of analysis, e.g., extraction of dwelling units (objects) versus delineation of settlements (areas). Thus the scale varies from small objects (e.g., slum buildings that can be below $20 \mathrm{~m}^{2}$ ) to large settlements of several hectares $[8,82]$. Furthermore, the required spatial, spectral and temporal resolution for slum mapping need to be specified. These requirements are closely linked to extraction methods. Across studies, a multiplicity of extraction methods for slum mapping have been employed, from classical visual image interpretation to OBIA or machine learning, or a combination of methods, with the main methodological challenge of translating a relevant set of slum characteristics into robust indicators (e.g., developing a slum ontology) for image-based slum mapping [23] that would ultimately allow for a global slum inventory.

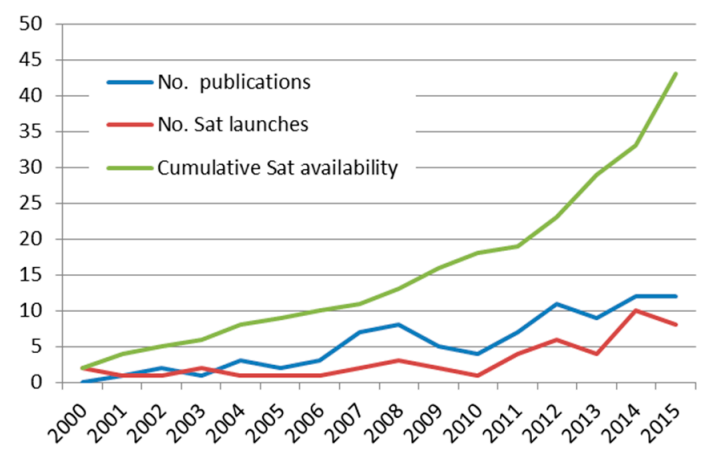

Figure 1. Number of publications on slums and remote sensing methods by year and successfully launched VHR satellites ( $\mathrm{r}^{2}$ is 0.75$)$.

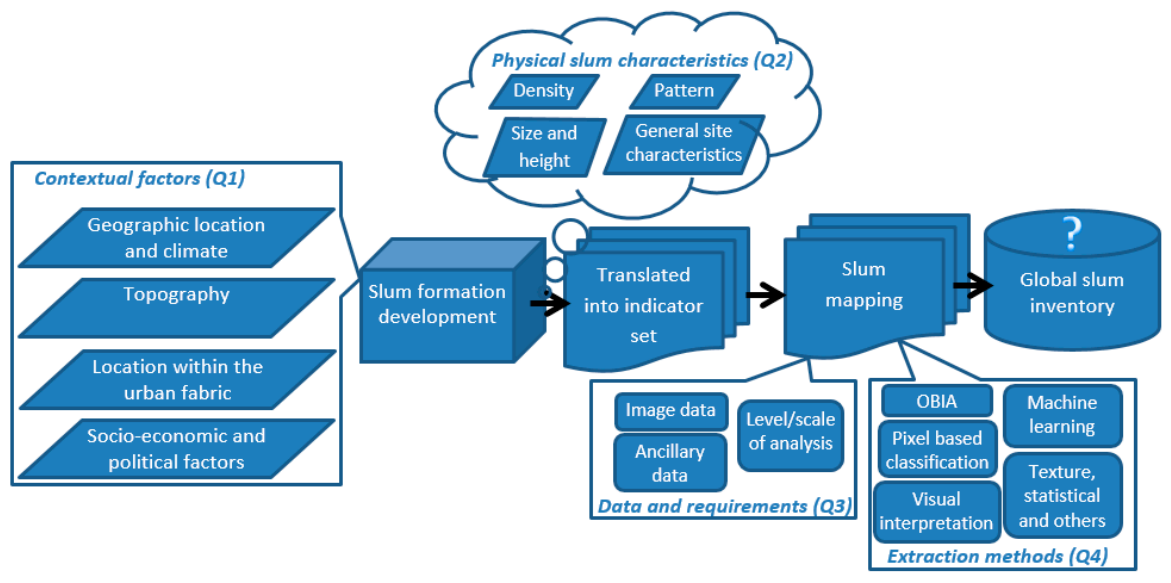

Figure 2. Analytical frame of the review: methodological challenge for a global slum inventory.

The overall purpose of this review is the identification of the variety of methodological advances in slum mapping that are relevant for a global slum inventory. Four analytical sub-questions guide this review. First, what are the main contextual factors and related slum terminologies of published studies on slum identification via RS (Q1)? Second, what are the varieties of physical slum characteristics 
extracted in VHR imagery (Q2)? Third, what are the input data and requirements of slum-mapping studies (Q3)? Fourth, which extraction methods have been used and what are their capacities, accuracies and limitations (Q4)? Each sub-question is dealt within one of the following sections.

\section{Contextual Factors}

Context matters for slum mapping. We first provide an overview of the terminological differences regarding settlements with poor living conditions as they affect the choice and definition of indicators. We also summarize the purposes of slum-mapping studies linked to the socioeconomic and political context. The final section gives an overview of geographic locations mapped by slum studies linking to variation in climate and topography.

\subsection{Terminological Differences}

The nomenclatures of slum settlements vary depending on different connotations [41,122]. To some extent, these terms reflect the different views on such settlements. Terms such as "informal," "illegal" or "squatter," for instance, focus on the land rights (tenure status) [24], whereas "unplanned" relates to the planning context [41]. "Spontaneous" or "irregular" emphasizes the growth dynamics [123], whereas "deprived," "shantytown" and "sub-standard" are associated with poor physical and socioeconomic conditions [54]. The recent revival in popularity of the rather political term "slum" [122] is largely linked to the Habitat Agenda and the related development goals [27,124]. The analysis of the retrieved publications with respect to these terms in combination with RS methods (see Table 2) identified "informal settlement/area" (47\%) and "slum" (29\%) as the most commonly used terms in the RS community, among which some researchers use both terms interchangeably $(6 \%)$. Less frequently used terms that refer to the physical condition (e.g., "deprived/sub-standard") focus on a specific issue (e.g., "refugee camps") or on a specific national context (e.g., "migrant housing" or "urban villages" in China). Terms such as "squatter" or "unplanned," which were common in the 1970s-1980s planning literature, are no longer commonly used. "Informal settlement/area" being the most frequently used term in the RS literature is actually awkward as it constitutes the legal (tenure) status of an area, which cannot be directly extracted from imagery. A change in tenure status does not necessarily affect the physical characteristics. In this review, we use the term "slum" to refer to urban areas with poor living conditions as this term expresses explicitly physical characteristics such as high densities or irregular patterns, indicators that can be derived by means of RS methods. Here, an ontological framework (e.g., developed by [5,7]) "provides a comprehensive description of spatial characteristics and their relationships to represent and characterize slums in an image" ([31], p. 155). Such an ontology framework-split in three phases: specification, conceptualization and implementation [5] — provides a clear conceptual foundation for developing robust image-based indicators, facilitating global knowledge acquisition and comparisons for the development of a global slum inventory.

Table 2. Frequency of publications using a specific term (within the reviewed remote sensing publications).

\begin{tabular}{ccc}
\hline Terms & Frequency & Percent (\%) \\
\hline Informal settlement/area & 41 & 47.1 \\
Slum & 25 & 28.7 \\
Slum and informal settlement/area & 5 & 5.8 \\
Squatter area & 4 & 4.6 \\
Unplanned area & 3 & 3.5 \\
Deprived area & 2 & 2.3 \\
Refugee camp & 2 & 2.3 \\
Sub-standard area & 2 & 2.3 \\
Informal homesteading & 1 & 1.1 \\
Informal and unplanned settlement & 1 & 1.1 \\
Migrant and informal housing & 1 & 1.1 \\
\hline Total & $\mathbf{8 7}$ & $\mathbf{1 0 0}$ \\
\hline
\end{tabular}




\subsection{Purposes of Slum Mapping Using Remote Sensing}

Our second contextual topic concerns the different purposes of RS-based slum-mapping studies. The review has identified three key geographical questions-where, when and what?-as the main objectives of studies. Often, researchers aim at the provision of basic information on "where" the slums are located within the urban fabric and what their areal extent is. Such information allows compensating for the non-availability of socioeconomic information (e.g., income levels) in many cities of the Global South [31]. Besides its importance for urban development [68], the where question is also relevant within a humanitarian context, for which several studies $[67,76,109]$ developed methods to map refugee camps (e.g., under Copernicus) [125].

While development dynamics of slums at the city scale are of particular interest for local planning and decision support $[10,126]$, only a few studies have focused on temporal slum dynamics (when) (e.g., [10]). This could be related to challenges extracting these dynamics, in particular in terms of data availability and obtaining local knowledge. Examples of studies on dynamics are the analysis of the process of forced mass evictions in Harare (Zimbabwe) [104], the investigation of built-up changes for large slum settlements such as Kibera-Nairobi [3] or the exploration of development dynamics of slums in Delhi, showing stagnation in the center versus growth in the periphery [127]. Such multi-temporal information can feed simulation models on the growth of slum areas, generating policy-relevant information of future growth scenarios [48,128-132].

Several publications have focused on what'-related issues, such as the number of slum inhabitants, since many census statistics slums are not well covered (with high uncertainty about the number of inhabitants) [133]. Moreover, RS-based population estimates allow a more detailed spatial and temporal disaggregation $[133,134]$. However, population estimates of slums can vary [4] as illustrated for the case of Kibera (Nairobi) [3], where estimates differed by half a million people depending on the sample data used. For the slums in Hyderabad, India, Kit et al. [134] computed slightly lower image-based population figures than the figures reported by the census. Furthermore, relying on physical proxies for population estimations can lead to errors for areas that have not yet been fully occupied, e.g., new developments in outskirts [70]. Other what-related issues deal with boundaries and effectiveness of policies for health campaigns [84,135], allocation of public services and protection of environmentally sensitive areas [68] or spatial planning and policy formulation [69]. These efforts are related to the fact that local planning authorities often lack elementary information on slums, which "has led to a deficit in policy for these areas, as without quality map data, it is often difficult to plan effectively for these areas" ([69], p. 390), leading to ad hoc plans that do not consider the specific locational context. For example, for one settlement in Johannesburg, Gunter [69] mapped 10,000 more dwellings by using Google Earth (GE) images compared to the government estimates. Such discrepancies are problematic for policy development and monitoring and may point to conceptual differences in what constitutes a slum dwelling. Spatial information on slums can support local governments in better determining the demand of basic services and other relevant amenities [136] and monitor slums via RS-based proxies of "human deprivation or well-being" ([137], p. 68).

The potential application areas for RS-based information on the morphology and temporal dynamics of slums are grouped into four major domains (Table 3, [21,54,77,120,138-152]): economy, environment, governance and planning, and social applications. These domains reflect the reported spatial information needs and lack of information on slums in locally available data sets [84]. Quite a rich body of literature is connected to social issues, where "remotely sensed imagery can serve as data source for inferring socio-economic variables" ([93], p. 69). Emerging applications areas are related to land management [144,145], quality of life and crime studies [151,152]. 
Table 3. Application domains of remote sensing-based information on the morphology and temporal dynamics of slums.

\begin{tabular}{lll}
\hline \multicolumn{1}{c}{ Domain } & & \multicolumn{1}{c}{ Application Areas } \\
\hline Economy & - & Economic condition-poverty, e.g., [138] \\
\hline \multirow{3}{*}{ Environment } & - & Environmental deprivation, e.g., [139] \\
& - & Environmental protection, e.g., [140,141] \\
& - Hazards—vulnerability, e.g., [142,143] \\
\hline \multirow{3}{*}{ Governance/Planning } & - & Land management-enumeration, e.g., [144,145] \\
& - & Urbann governance, e.g., [54] \\
\hline & - & Health, e.g., [120,147,148] \\
Social & - Humanitarian, e.g., [76,149,150] \\
& - & Quality of life and crime, e.g., [151,152] \\
\hline
\end{tabular}

\subsection{Geographic Locations, Climate and Topography}

Given the aim of identifying relevant issues for developing a global slum inventory, we analyze the geographic distribution of RS-based information on slums by mapping the case study locations found in English-language publications on top of a population density map (Figure 3). In the figure, "slum cities" are grouped into locations where object-level information (roofs or roads), area-based slum maps, or both were extracted. Object-level information is mainly available in SSA. Obviously, there is a spatial relationship between areas of high urban population densities in the Global South and the location of case studies. The highest concentrations are found in South-East Asia and SSA (East and South). Some clusters also exist in North and West Africa and South/Central America. Examples are even found in the Global North, dealing with the monitoring of informal development, e.g., in Greece [153] and the US [119]. The cities covered range from (sub)tropic, Mediterranean, arid and continental climates, as well as low-lying areas with rather flat terrain (e.g., Dhaka) up to high-lying cities (e.g., La Paz) with steep slopes. Still, many urban regions with very dynamic urban and slum developments are not well covered in English-language publications, e.g., areas in the Caribbean, West and Central Africa or in South-East Asia. Also, areas in Europe might become a future focus, considering the recent erection of refugee camps or examples of deprived Roma settlements in European countries [144]. Many of the regions not covered belong to the least developed countries with large income inequalities and/or instable political conditions, e.g., Liberia, Congo or Myanmar. In such countries, ground-truth or reference data accessibility might be even more of a problem. Moreover, many studies are about methodological developments and do not create exhaustive citywide slum maps, illustrating that we are still far away from a global slum inventory.

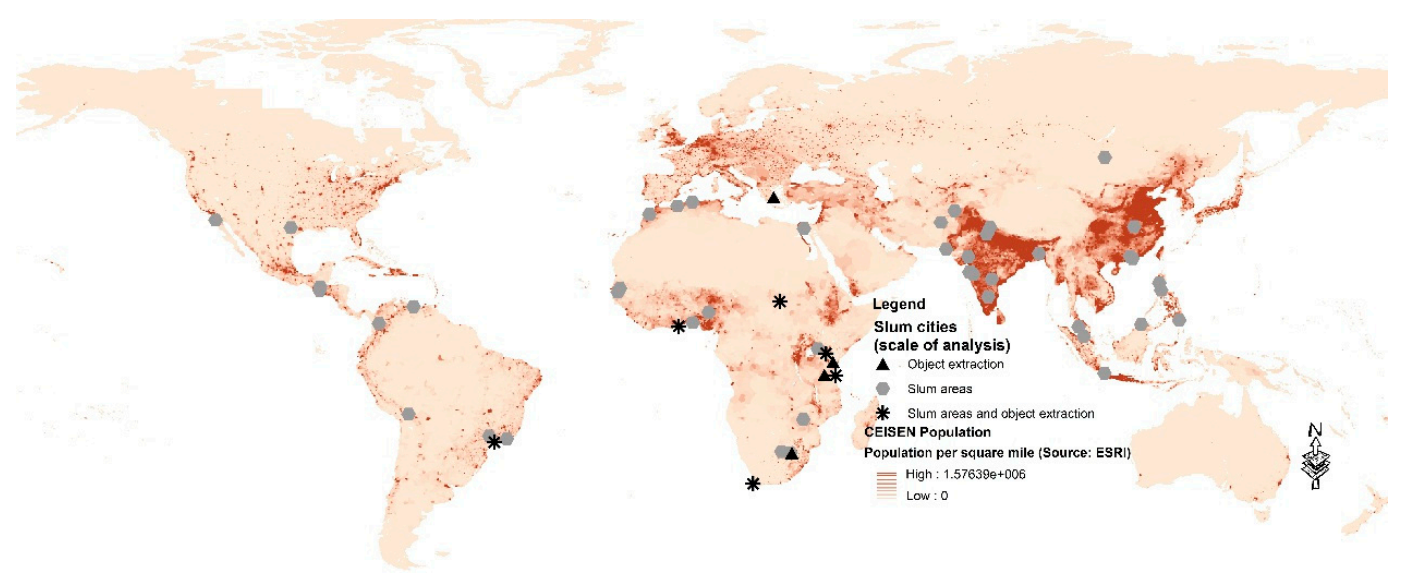

Figure 3. Case study cities in publications $(N=87)$ on slum mapping via RS methods on top of a population density map (base map: population density, Source: ESRI). 
The majority of the reviewed publications are authored by academic researchers, both from universities in the Global North $(48 \%)$ and Global South $(21 \%)$ or combinations thereof $(6 \%)$. Fewer publications stem from research centers (including national RS agencies), in the Global North $(8 \%)$ and Global South $(5 \%)$ and one by a commercial image provider $(1 \%)$. Moreover, there is some cooperation between research centers and university in the Global North (5\%) and South $(2 \%)$, also across South and North (2\%), or with an NGO (2\%). The majority of English-language publications from the Global North links to the global slum debate. South-North and South-South cooperation are of particular relevance for knowledge exchanges and transfer, bridging technology gaps and for further expanding our knowledge to more cities including also very instable regions like the Sudan [125].

\section{Physical Characteristics of Slum Areas}

VHR imagery provides a detailed representation of the physical elements of a landscape, capturing physical characteristics of slums. This section conceptualizes these characteristics derived from imagery and considers their diversity.

\subsection{Characterization of Slum Areas}

The definition of what constitutes a slum is complex. Variations exist between global, regional and local slum definitions [154] that can result in large differences of mapped slum areas [64]. Many publications adopted the global UN-Habitat definition of slums (e.g., $[4,43,155])$, which consists of five well-established indicators: secure tenure, adequate access to safe water, access to acceptable forms of sanitation, overcrowding, and the durability of housing considering both the quality of the structures as well as site conditions in terms of hazards. For instance, based on the work of Weeks et al. [43], Duque et al. [61] used these indicators (i.e., wall material, overcrowding, access to piped water, sanitation connection to sewers, and ownership) to build a slum index based on census data for the city of Medellin (Colombia). This index, compared with image-based information on land cover, structural and texture-based features, showed that the image-based information could explain $59 \%$ of the slum index. A major problem in employing the UN-Habitat definition in RS-based studies is that only the indicator "durability of housing conditions" has a direct link to information extracted from imagery, namely location aspects (such as location on steep slopes, along major drainage channels [112]), compliance with building codes measured via density, distance or roofing material [2]. Slums do not have "easily distinguishable spectral signatures" ([45], p. 661), meaning that roofing material may vary within slums (e.g., plastic, iron, concrete, tin, asbestos) and between different slums and globally between cities. For the example of Accra (Ghana), Engstrom et al. [64] concluded that when using the UN-Habitat definition, most of the city is classified as slums, while an image-based identification matched much better the local delineation of slums. These examples indicate that global slum definitions need to be adjusted to the local context. However, most researchers fail to start with a local characterization of the slum morphology and the development of related image-based proxies.

Table 4 presents an overview of physical characterizations of slums found in literature, split into five major dimensions: building geometry, density, arrangement (pattern/road), roofing material, and site characteristics. The most frequently used characteristics are small roof sizes, high density, and irregular patterns (visible by irregular and narrow streets combined with heterogeneous building orientation). Densities in Asian cities tend to have higher values than in SSA cities (Asia $~ 80 \%$ and SSA $\sim 60 \%$ ) [5,41]. However, also in SSA, centrally located slums, such as those in Nairobi, Kenya with an estimated roof cover of $50 \%-60 \%$, have high densities [156]. For the group of roofing material and physical site characteristics, there is a great deal of difference between cities across different geographic regions and even across slums. For instance, in Dehradun, slums are characterized by tone differences due to different roofing materials (e.g., plastic, wood etc.) [75], but in Guangzhou [97] or Ahmedabad [5], spectrally similar roofing material characterizes slums. Regarding physical site characteristics, there is also no general agreement; however, slums are often located in areas that are not suitable for constructions (e.g., on a flood plain, steep slope or other hazardous locations) [157]. 
Table 4. Physical characteristics of slums in selected journal papers.

\begin{tabular}{|c|c|c|c|c|c|c|}
\hline & Geographical Area & Building Geometry & Density & Arrangement Pattern/Roads & Roofing Materials & Site Characteristics \\
\hline \multirow{9}{*}{$\underset{4}{4}$} & Ahmedabad [5] & Small roof sizes, number of floors & High density & $\begin{array}{l}\text { Absence and/or irregular } \\
\text { roads (width/unpaved) }\end{array}$ & $\begin{array}{l}\text { Specific roof materials (e.g., } \\
\text { iron, plastic) }\end{array}$ & $\begin{array}{l}\text { Lack of green/open spaces, } \\
\text { irregularly shaped boundaries }\end{array}$ \\
\hline & Bangalore [84] & Low building height & $\begin{array}{l}\text { Limited space between shelter } \\
\text { units }\end{array}$ & $\begin{array}{l}\text { Lack of access roads and } \\
\text { irregular patterns }\end{array}$ & Specific (brown or grey roofs) & Lack of shadow \\
\hline & Dehradun [75] & Small roof sizes & & Irregular patterns & $\begin{array}{l}\text { Diverse (plastic, wood, } \\
\text { cement/concrete) }\end{array}$ & \\
\hline & Delhi [54] & Small roof sizes & High density $\sim 80 \%$ & $\begin{array}{l}\text { Irregular patterns; no access } \\
\text { roads }\end{array}$ & & $\begin{array}{l}\text { Hazardous locations (e.g., } \\
\text { railway, river, highway) }\end{array}$ \\
\hline & Delhi [94] & Small roof sizes, mostly 1-2 floors & High density & $\begin{array}{l}\text { Irregular patterns; narrow } \\
\text { streets in bad conditions }\end{array}$ & $\begin{array}{c}\text { Diverse poor and } \\
\text { non-permanent materials }\end{array}$ & $\begin{array}{l}\text { Complex settlement shape, } \\
\text { hazardous locations) }\end{array}$ \\
\hline & Hyderabad $[10,45]$ & Small roof sizes & High density & $\begin{array}{l}\text { Irregular patterns; } \\
\text { narrow streets }\end{array}$ & & $\begin{array}{l}\text { Often at city edge and close to } \\
\text { industrial sites. }\end{array}$ \\
\hline & Mumbai [4] & $\begin{array}{l}\text { Small roof sizes }\left(<60 \mathrm{~m}^{2},\right. \\
\text { average height } 2.3 \text { floors })\end{array}$ & $\begin{array}{l}\text { High density }>50 \% \text { : narrow } \\
\text { streets / footpaths (below } 1 \mathrm{~m} \text { ) }\end{array}$ & $\begin{array}{l}\text { Low heterogeneity of spatial } \\
\text { patterns }\end{array}$ & & \\
\hline & Guangzhou [97] & $\begin{array}{c}\text { Mostly square roofs }(\sim 12 \times 12 \mathrm{~m}) \\
\text { additional floors }\end{array}$ & $\begin{array}{l}\text { High density; distance between } \\
\text { shelters } 1 \text { to } 3 \mathrm{~m}\end{array}$ & $\begin{array}{l}\text { Patterns vary depending on } \\
\text { location }\end{array}$ & Specific (spectrally similar) & \\
\hline & Shenzhen and Wuhan [72] & Small roof sizes & High density & Irregular patterns & $\begin{array}{l}\text { Often specific } \\
\text { roofing material }\end{array}$ & $\begin{array}{l}\text { Little vegetation and other } \\
\text { open spaces }\end{array}$ \\
\hline \multirow{4}{*}{ 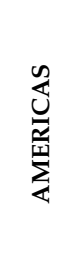 } & Guatemala City [6] & $\begin{array}{l}\text { Small roof sizes, simple shapes, } \\
\text { diverse orientation }\end{array}$ & High density & Irregular patterns & Diverse & $\begin{array}{l}\text { Dirt roads; less green; poor } \\
\text { accessibility; steep slope; } \\
\text { proximity to hazards }\end{array}$ \\
\hline & Medellin [61] & Small roof sizes & High density & Complex patterns & Diverse & \\
\hline & Rio de Janeiro, Brazil [44] & Small roof sizes & High density & Irregular patterns & & \\
\hline & Sao Paulo State [96] & Small roof sizes & High density & & $\begin{array}{c}\text { Specific (ceramic tile } \\
\text { and asbestos) }\end{array}$ & Lack of vegetation \\
\hline \multirow{3}{*}{ कీ } & Accra [120] & Small roof sizes & High density & & Specific (spectrally similar) & Lack of vegetation \\
\hline & Cape Town [87] & Small roof sizes & & & $\begin{array}{l}\text { Diverse (e.g., plastic, } \\
\text { tin, wood) }\end{array}$ & $\begin{array}{l}\text { Degradation of the local } \\
\text { ecosystem }\end{array}$ \\
\hline & Nairobi [74] & Small roof sizes & High density; narrow roads & Irregular patterns & $\begin{array}{l}\text { Specific (with low } \\
\text { reflectance) }\end{array}$ & \\
\hline \multirow{3}{*}{\begin{tabular}{l} 
D \\
0 \\
\multirow{2}{*}{}
\end{tabular}} & $\begin{array}{c}\text { Caracas, Kabul, Kandahar, } \\
\text { La Paz [46] }\end{array}$ & Small roof sizes & High density & $\begin{array}{l}\text { Heterogeneity in building } \\
\text { orientation, irregular streets }\end{array}$ & Diverse & $\begin{array}{c}\text { Proximity to } \\
\text { hazardous locations }\end{array}$ \\
\hline & $\begin{array}{c}\text { Cape Town, } \\
\text { Rio de Janeiro }[7,71]\end{array}$ & Small roof sizes & High density & $\begin{array}{l}\text { Irregular patterns, small } \\
\text { road segments }\end{array}$ & Irregular building materials & $\begin{array}{l}\text { Only small patches of } \\
\text { vegetation cover }\end{array}$ \\
\hline & Delhi, Dar es Salaam [41] & Small roof sizes & High density & Irregular patterns & & \\
\hline \multicolumn{2}{|c|}{ Frequency: Asia: 11, Americas: 6, SSA: 5} & 19 & 17 & 16 & 14 & 12 \\
\hline
\end{tabular}


To conceptualize such physical characteristics, Kohli et al. [5] developed a slum ontology (Figure 4), based on Hofmann et al. [7], which consists of three spatial levels (object, settlement and environs). For each level, indicators identify specific physical slum characteristics. Yet the ontology requires a local adaption as not all indicators are relevant for a specific local slum identification [158]. Thus slums are different from non-slum areas, but are not homogeneous [4].

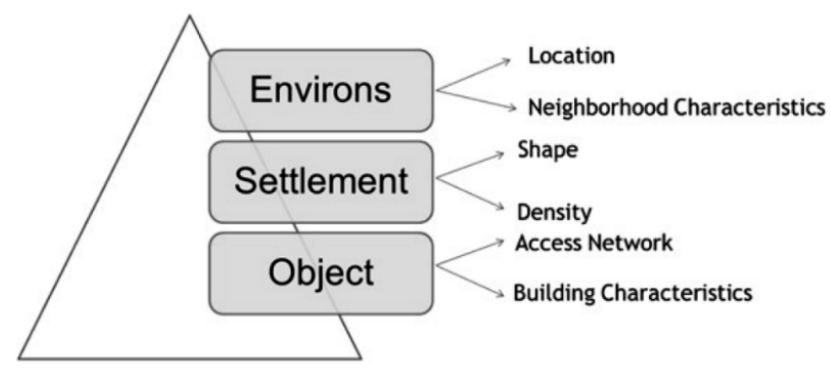

Figure 4. Slum ontology—indicators associated with the three spatial levels [5].

\subsection{The Diversity of Slums}

Besides the commonalities of slums in terms of physical characteristics, we also explore the heterogeneity of slums. Already in 1962, Charles Stokes differentiated between "slums of hope" and "slums of despair" [159]. Slums vary between and within cities and within slums in terms of sub-standard living conditions $[122,160]$. Therefore, recently, some researchers have been exploring different slum typologies based on building sizes, density, pattern or location (Table 5). However, slums are often not the worst off areas in terms of socioeconomic conditions [31,114,161]. Thus, such typologies include also fuzzy classes (i.e., semi-formal), reflecting the dilemma that some areas are formal but are physically and/or socioeconomically similar to slums, e.g., high-density resettlement colonies in Delhi [54]. On the contrary, areas can have morphological characteristics that align with slums, but on the ground, they are not slums like historic core areas.

Table 5. Slum typologies and their categories.

\begin{tabular}{|c|c|c|}
\hline No. & Categories & Geographical Area \\
\hline 2 & $\begin{array}{l}\text { - } \quad \text { Semi-formal low-cost housing } \\
\text { - } \quad \text { Slum }\end{array}$ & Quezon City [65] \\
\hline 2 & $\begin{array}{l}\text { - Type I: small- to medium-sized buildings, } \\
\text { narrow/irregular streets } \\
\text { - Type II: very small buildings and high building } \\
\text { density, unidentifiable roads }\end{array}$ & Caracas, Kabul Kandahar, La Paz [46] \\
\hline 3 & $\begin{array}{ll}\text { - } & \text { Informal A (squatter settlement) } \\
\text { - } & \text { Informal B (precarious encroachments) } \\
\text { - } & \text { Basic formal areas (often resettlement colonies }\end{array}$ & Delhi [54] \\
\hline 5 & $\begin{array}{ll}\text { - } & \text { Slum pocket } \\
\text { - } & \text { Slum area with small buildings } \\
\text { - } & \text { Slum area with mix small/large buildings } \\
\text { - } & \text { Slum area with larger buildings/chawls } \\
\text { - } & \text { Basic formal areas }\end{array}$ & Mumbai [85] \\
\hline
\end{tabular}

The established typologies (Table 5) range from two to five categories. The main factor that influenced authors to develop such typologies is the diversity on the ground, e.g., very deprived areas and areas that have an unsecure tenure status but are better off in terms of building characteristics. Some differences are visible in imagery and may assist in a semi-automatic slum identification. However, none of the reviewed studies established an (semi)-automatic image-classification approach to extract slum typologies. 


\section{Data Availability and Spatial Requirements}

The complexity of physical slum characteristics requires advanced sensor systems for mapping purposes. This section focuses on available imagery data and the spatial requirements in terms of spatial resolution and extent (settlement to urban region level) of reviewed studies.

\subsection{Our Remote Eyes: Available Sensors}

The successful launch of Ikonos-2 on 24 September 1999 heralded a new era of urban RS. The increased availability of high and very-high-resolution imagery produced by sensors such as Ikonos, QuickBird, WorldView (very-high-resolution sensors (VHR) have spatial resolutions of the PAN band of $1 \mathrm{~m}$ and below, while high-resolution (HR) sensors have between 1 and $5 \mathrm{~m}$ spatial resolutions) have provided a new and rich data repository for urban research in general and for slum-related research in particular, as it allows for a more detailed spatial analysis [162]. Besides commercial VHR imagery, since 2005, GE has provided universal web-based access to VHR imagery, although not providing the original spectral bands, which limits potential analysis.

An increasing number of multi-spectral (MS) and panchromatic (PAN) VHR sensors has become available (see Figure 5). For instance, since August 2014, the first commercial satellite with a spatial resolution of $0.31 \mathrm{~m}$ (PAN) and $1.24 \mathrm{~m}$ (MS) allows an improved object-level analysis. While the first sensors were launched by countries in the Global North, there is an increasing number of launches of (V)HR sensors by countries in the Global South (such as NigeriaSat). Also, China has launched a large number of (V)HR sensors; however, access to data from outside China is an issue. Besides optical systems, synthetic aperture radar (SAR) systems are gaining an increasing role in extracting information on slums, especially since the availability of (V)HR systems, e.g., PALSAR: $7 \mathrm{~m}$ (2006), Terra SAR-X: $1 \mathrm{~m}$ (2007), SENTINEL-1: 5 m (2014).

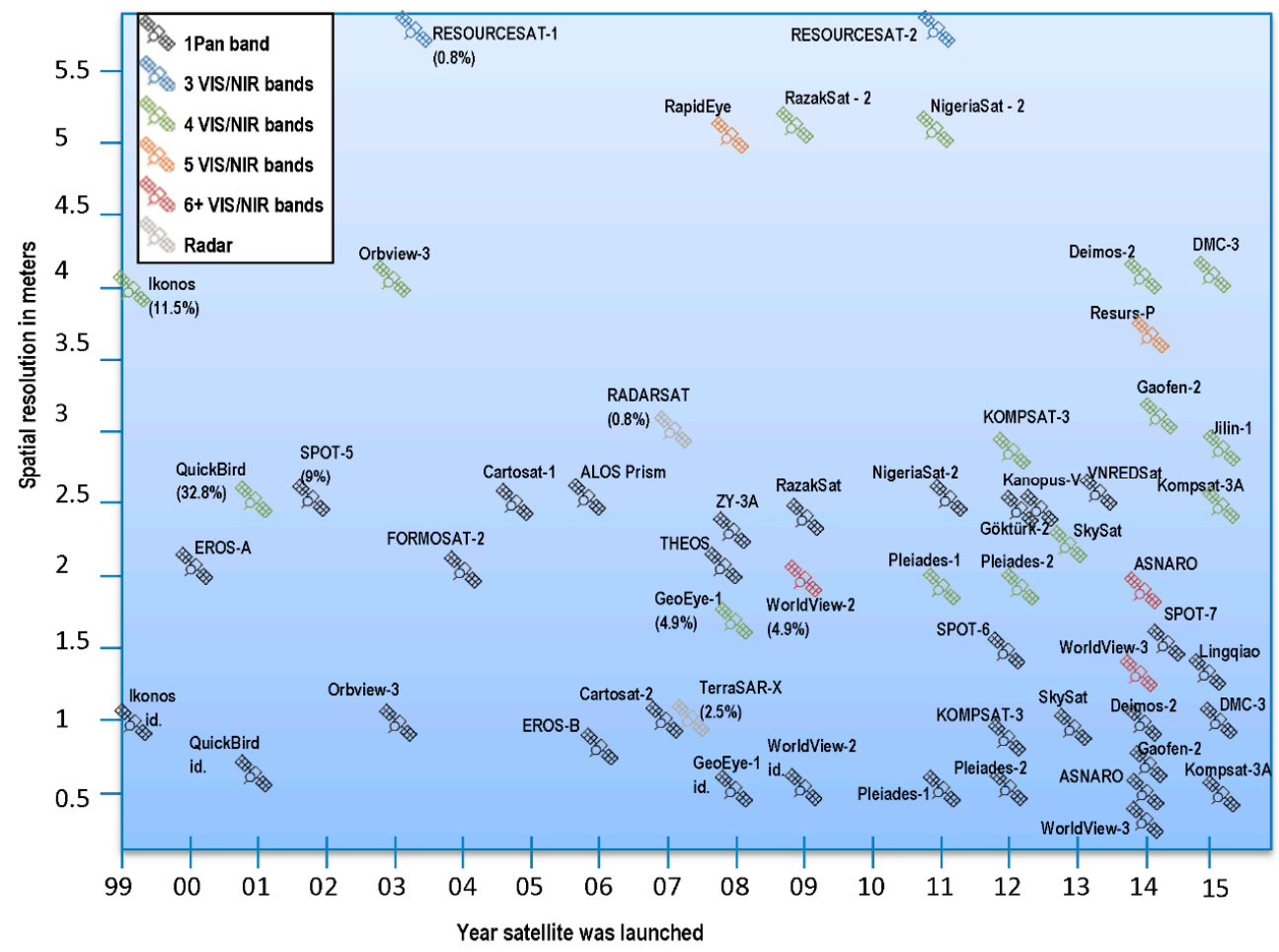

Figure 5. Overview spatial and temporal characteristics of very high and high-resolution satellites; in brackets: percentage of image data sources of reviewed publications (percentages are displayed for the MS bands (when available): this combines the percentage of MS and PAN bands) ( $N=122$, some publications use multiple image data, in addition to aerial sensors: $8.2 \%$, GE: $6.6 \%$, and moderate resolution systems: Landsat: 8.2\%, Envisat ASAR: 4.9\%, Terra ASTER: 2.5\%, PALSAR: 1.6\%, MODIS: 0.8\%). 
Analyzing the imagery used in the reviewed studies (Figure 5), we identify QuickBird, launched in 2001 with a spatial resolution of 0.61 and $2.44 \mathrm{~m}$ (PAN and MS) and a revisit time of 3 days, as the most frequently used sensor (33\%). The revisit time does not equal repetition rate, e.g., WV-3 needs 4.5 days until capturing a scene with the same geometric characteristics $\left(20^{\circ}\right.$ off-nadir or less at exactly the same position). While, images taken $<1$ day might have different geometric characteristics, e.g., causing problems for multi-temporal image comparison. The second most frequently used sensor is Ikonos (11\%), with a spatial resolution of 1 and $4 \mathrm{~m}$ and the same revisit time. This is followed by SPOT (mainly SPOT-5) (9\%), with a slightly lower spatial resolution (SPOT-5: Pan: 2.5/5 m and MS: $10 \mathrm{~m}$ ) and revisit time of 5 days; Landsat $(9 \%)$ and aerial photos/imagery $(8 \%)$. The latter have been an important spatial information source in mapping and analyzing (e.g., [163,164]), in monitoring growth processes (e.g., [73]) and in extracting buildings in slums (e.g., [102]). The main advantages of aerial photographs are that archives often cover long time series and have very high spatial resolutions (in cm range). Apart from the V(HR) imagery, some studies employed moderate resolution imagery (e.g., Landsat, Terra ASTER), e.g., analyzing vegetation cover in slums [110], which is often a good proxy for deprivation [165].

\subsection{Spatial Requirements of Slum-Mapping Studies}

Spectrally most of the imagery have 2-3 VIS bands and 1-2 IR bands, and the availability of more VHR sensors with more spectral bands (e.g., Worldview- 2 with 8 bands) producing images of improved spatial resolutions raises the question of what is an optimal or minimum spatial resolution for slum mapping. In this respect, Jacobsen and Büyüksalih [166] determined the required GSD (ground sampling distance) for building objects to be $2 \mathrm{~m}$ and for footpaths 1-2 $\mathrm{m}$, while for minor roads $5 \mathrm{~m}$ was considered sufficient. However, detailed building object information requires below $0.5 \mathrm{~m}$ and a sufficient contrast between buildings and their surrounding [167]. Moreover, this may vary in different urban environments. For instance, in cities with a high clustering of buildings, such as in many Asian cities, a resolution of $2 \mathrm{~m}$ does not allow the extraction of roof objects [41]. Furthermore, according to Pesaresi and Ehrlich ([168], p. 45), when "assuming a typical minimal built-up element in a settlement, having a size of $10 \times 10 \mathrm{~m}$, we need at least $0.5 \mathrm{~m}$." Many slum buildings are, however, considerably below $100 \mathrm{~m}^{2}$. Moreover, roof surfaces are frequently not homogeneous; for instance, when using a VHR sensor, the majority of the roof pixels will be "mixed pixels" (due to different materials/shadow/illumination) [168]. Consequently, not only the high densities of roofs, but also the heterogeneity of roof surfaces causes serious limitations for automatically extracting roof objects, subsequently requiring manual editing for producing reliable information [169]. There is as of yet no systematic study that analyzes the impact of different spatial and spectral resolutions on the accuracy of extracting object-level information in slums. It is also interesting that most studies on roof $[55,73,87,91]$ or road extraction [95] are from African cities (see also Figure 3), where coverage densities and clustering of roofs are in general a bit lower than in Asian cities [5].

Considering the high costs for commercial VHR imagery and the required processing resources, many studies have focused on methodological advances and therefore only used as spatial extent small areas, e.g., subsets of scenes (34\%) and settlements (24\%) or administrative units $(9 \%)$ (Table 6). Methods developed for one scene segment are not necessarily transferable to other scenes [105]. However, more than one-quarter performed the analysis for an entire city $(28 \%)$ or at urban region scale (5\%). The city and urban regional scale are important stepping stones for building a global slum inventory. A further stepping stone towards a global slum inventory is a recent pilot study to map slums of an entire country (South Africa) [77]. 
Table 6. Spatial extent (scale) of slum-mapping case studies found in literature.

\begin{tabular}{ccc}
\hline Scale & Frequency & Percent (\%) \\
\hline Settlement & 21 & 24.1 \\
Ward/district & 7 & 8.1 \\
Subset & 30 & 34.5 \\
City & 24 & 27.6 \\
Urban region & 4 & 4.6 \\
Country & 1 & 1.1 \\
\hline Total & $\mathbf{8 7}$ & $\mathbf{1 0 0}$ \\
\hline
\end{tabular}

\section{Slum-Mapping Approaches}

Among the reviewed studies, multiple methods have been used to map slums. This section focuses on the most promising methods with respect to extracted information level (objects or areas) and achieved accuracies. In general, the level of analysis depends on the spatial resolution of available imagery, the specific urban morphology and the information requirements.

\subsection{Methods Employed for Slum Mapping}

In order to explore the discursive context of slum-mapping efforts, we analyze the actual information that is extracted in the reviewed case studies (Table 7 rows). The majority $(55 \%)$ of studies identify entire slum areas $[74,82,100]$, and fewer studies aim at extracting objects in slums $(15 \%)$, i.e., roofs [40,87] or roads [95]. The extraction of object-level information depends largely on the relation between (available) data sources and morphological characteristics of the study area, meaning that roof or road extraction works well when objects have clearly visible spacing and contrast in the imagery. The more classical focus on extracting land use/cover information is addressed by $17 \%$ of the publications (e.g., [96,101]). Within this category, a recent research stream aims at mapping built-up areas using, for example, texture measures. Here, the co-occurrence matrix (GLCM) is commonly used (e.g., $[62,170,171])$, which is also the basis for the "anisotropic rotation-invariant built-up presence index" (Pantex) [172]. Finally, a limited number of studies develop methodologies to analyze the link between image-based and socioeconomic indicators (6\%) (e.g., [173]) or the diversity of slums (7\%) (e.g., [85]).

Table 7. Frequency of methods versus main focus for slum mapping using VHR imagery.

\begin{tabular}{|c|c|c|c|c|c|c|c|c|c|}
\hline & & \multicolumn{7}{|c|}{ Methods } & \multirow[b]{2}{*}{$\begin{array}{l}\text { Total Number } \\
\text { (Percentage) }\end{array}$} \\
\hline & & $\begin{array}{l}\text { Contour } \\
\text { Model }\end{array}$ & $\begin{array}{l}\text { Machine } \\
\text { Learning }\end{array}$ & $\begin{array}{c}\text { Object- } \\
\text { Based } \\
\text { Approach }\end{array}$ & $\begin{array}{l}\text { Pixel-Based } \\
\text { Approach }\end{array}$ & $\begin{array}{l}\text { Statistical } \\
\text { Model }\end{array}$ & $\begin{array}{c}\text { Texture/ } \\
\text { Morphology }\end{array}$ & $\begin{array}{l}\text { Visual Image } \\
\text { Interpretation }\end{array}$ & \\
\hline \multirow{4}{*}{ రৃ } & $\begin{array}{c}\text { Correlation with } \\
\text { socioeconomic indicators }\end{array}$ & 0 & 0 & 1 & 3 & 0 & 0 & 1 & $5(5.7 \%)$ \\
\hline & $\begin{array}{l}\text { Extractions of roofs/roads } \\
\text { (objects) }\end{array}$ & 4 & 0 & 7 & 0 & 0 & 1 & 1 & $13(14.9 \%)$ \\
\hline & Land use/cover mapping & 0 & 2 & 4 & 5 & 1 & 3 & 0 & $15(17.2 \%)$ \\
\hline & Total Number (Percentage) & $4(4.6 \%)$ & $11(12.6 \%)$ & $28(32.2 \%)$ & $11(12.6 \%)$ & $4(4.6 \%)$ & $14(16.1 \%)$ & $15(17.2 \%)$ & $87(100 \%)$ \\
\hline
\end{tabular}

Since the expert meeting on slum mapping in 2008 [36], more methods and cases on slum cities have been explored, expanding the global knowledge repository of slum characteristics and their variability. Brito and Quintanilha [174] stated that in recent years many methods have been based on feature extraction but there is no clear agreement on the most successful method(s), where the majority of studies rely on optical data. The availability of imagery with sub-meter resolution still has many unresolved technical challenges for the characterization of slums, such as mixed 
pixels or the obliqueness of images. Thus, there is "a strong need of new approaches for automatic image understanding on remote sensing data bridging the gap between visual and automatic image interpretation" ([175], p. 3). In this respect, also complex (visual) interpretation elements (e.g., height, shadow, pattern and site) (Figure 6, [41,176,177] ) need to be more systematically explored [177].
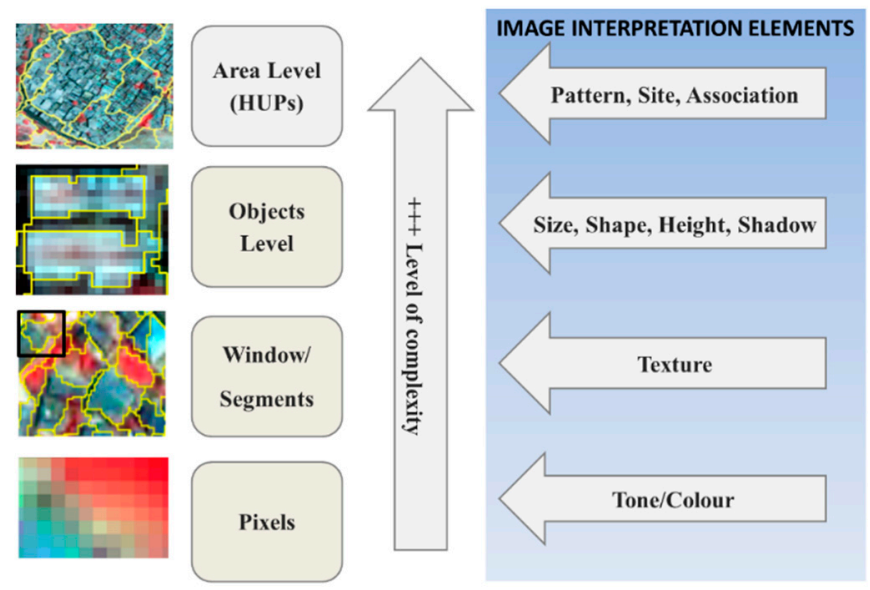

Figure 6. Complexity of image interpretation elements (adapted from [41,176,177]).

Already in 1998, Mason and Fraser [178] specified three main characteristics of an effective system to map/monitor slums, specifically low-cost (data acquisition and processing), semi-automated processes (fast and reliable results) and simple usage by low-skilled operators (standard software). The analysis of the employed methods in the reviewed slum publications shows that most studies used commercial and rather expensive imagery. Only very few studies used free data sources such as GE image, mostly for visual image interpretation (e.g., [69,84,119]), visualization of slums [90] or combining GE with commercial imagery [72,80], whereas Praptono et al. [98] used GE images to automatically detect slums employing a Gabor filter and GLCM with a promising accuracy of $74 \%$. Many of the methods used commercial software solutions, but to some extent also open-source software. Nevertheless, both are not easy to be operated by non-RS experts.

Overall, the methods to extract slums are rather diverse (Table 7 columns). The most frequently used method in the last 15 years was OBIA (32\%), also referred to as GEOBIA [179]. For OBIA, the transferability [82] or robustness [71] of rules and indicators is a critical issue, which is a stronger feature of texture or morphology-based methods [82], accounting for $16 \%$ of the studies. Significantly, Hofmann et al. [180] stressed that a systematic adaption of segmentation parameters is crucial to transfer rules from one image to another. Several studies focused on the optimization of scale parameters [181], where the tool Estimation of Scale Parameters (ESP) allows optimizing the scale based on patterns in the data [182].

Apart from OBIA, visual image interpretation (17\%) and standard pixel-based image classification were employed (13\%). However, the reliance on standard pixel-based classification methods is not that appropriate for analyzing a complex urban environment having high spectral diversity, very small and clustered objects and diverse morphological characteristics. Therefore, many researchers used machine-learning algorithms (14\%) such as neural networks [59], random forest (RF) or support vector machines (SVM) [72]. Machine-learning approaches are information-driven approaches that allow for a repetitive learning from a large and rich set of training data [94]. However, those approaches are mainly pixel-based methods, which are "not very effective in high-resolution urban image classification" procedures ([116], p. 869). Therefore, a large spatial context of many neighboring pixels is necessary, such as multi-instant learning [116] or Markov random fields [46]. Given that neighborhoods or wards are relevant spatial units of policy and decision-making processes, the issue of aggregation is important, via segments (e.g., [41,88]), regular grids (e.g., [104]) or non-overlapping block [173]. 
Crossing the main foci and methods (Table 7), OBIA appears to be the most common method for extracting both slum areas and objects in slums. Although rather labor intensive, visual interpretation is still used for slum identification, producing reliable results by skilled interpretations; however, texture/morphology and machine-learning methods are increasingly being used.

\subsection{Accuracy Levels and Employed Methods}

The last dimension of the analysis deals with the performance of indicators and methods, measured by accuracy levels. Across the studies, there is much diversity with respect to these levels. For instance, Ella et al. [63] compared various texture features (e.g., local binary pattern (LBP), GLCM, lacunarity) by training a support vector machine. While LBP achieved the highest accuracy of $98 \%$, GLCM had an accuracy of $94 \%$. Based on single indicator approaches, lacunarity was identified as having a high utility for extracting slums (e.g., [45,57]); however, lacunarity cannot identify small slum pockets as it requires a rather large window size [10]. Verzosa and Gonzalez [118] suggested entropy for monitoring uncontrolled sprawl, while the morphology of slums can be described by spatial metrics $[41,83]$ with reported accuracies of not more than $70 \%$. Besides the use of single or a small set of indicators, several studies used large sets of indicators. For example, Owen and Wong [6] performed a systematic comparison between indicators to distinguish formal and slum areas using 24 spectral, accessibility, texture, scale-based and morphological indicators. The result showed that the best indicators were entropy of roads, vegetation patch size, and vegetation patch compactness. Similarly, Graesser, Cheriyadat, Vatsavai, Chandola, Long and Bright [46] focused on the development of consistent predictors for formal and slum areas by a decision tree using GLCM, lacunarity, histogram gradients, linear feature distribution, line support regions, vegetation indices, and textons (texture patches). Their result showed that texton features were most robust for all included cities (i.e., Caracas, Kabul, Kandahar, and La Paz), achieving a maximum accuracy of 92\% [43]. Thus, a fully automatic system for mapping slums with $100 \%$ accuracy is not in sight. However, reported accuracy levels show promising developments for semi-automatic methods.

Apart from comparing the capacity of indicators, the performance of methods is evaluated. In general, advanced approaches (such as mathematical morphology analysis) have a better performance than standard classification approaches [67]. To evaluate the performance of methods, we compare the accuracy of all reviewed slum-mapping publications (Figure 7). The highest mean accuracy is obtained by machine-learning approaches, but also texture and statistical-based approaches show promising results, while the variance of the performance of OBIA is rather large. The cases of lower accuracies of OBIA are often related to very complex urban environments such as Indian cities where slum areas are very diverse and often have similar spatial characteristics compared to formal areas. Thus obtained accuracy levels not only depend on the methodology, but also on the urban morphology and how well slum characteristics are captured by image-based proxies. To address this, Shekhar [105] proposed an OBIA procedure, identifying first formal areas; the remaining built-up areas are then classified as slums achieving an overall accuracy of $87 \%$.

In conclusion, machine-learning methods seem to be more successful when aiming at extracting slum areas at the city scale, whereas OBIA was found to work well for the extraction of objects (e.g., roofs, roads) on settlement level when the urban morphology combined with a sufficient resolution image allowed their extraction. Both methods can be combined, e.g., using image segmentation together with machine-learning approaches [183], which allows combining the advantages of both methods. 


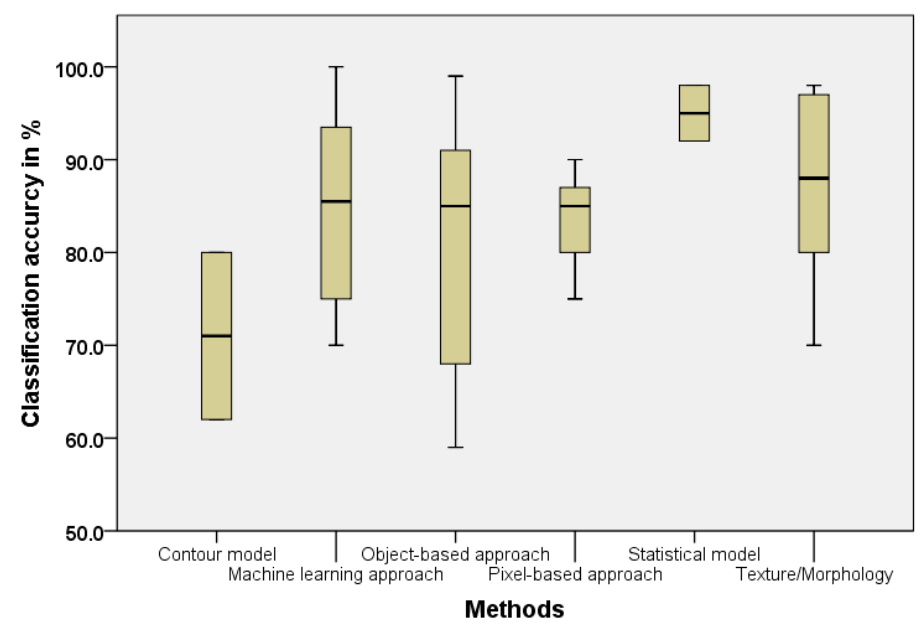

Figure 7. Reported accuracies for different image analysis methods on slum mapping.

\section{Challenges and Promising Aspects for a Global Slum Monitoring System}

Based on the results presented in the previous sections, the most promising aspects of the reviewed studies (in terms of context, physical characteristics, data and requirements, and methodologies) for developing a global slum inventory are explored.

\subsection{Access to Image Data and Contextual Factors}

Our geographic "ground" knowledge on slums is limited to a few urban regions. Therefore, Owen and Wong [38] recommended more systematic comparisons between different slum settlements, done by very few studies (e.g., [46]). It would be important to compare the performance of indicators, methods, and image data for different urban contexts across the globe to obtain an overview of robust indicators, methods, and required data. A major initiative in this respect is performed by the Oak Ridge National Laboratory, where researchers are working on "a computationally efficient and automated framework that is capable of detecting new settlements (especially slums) across the globe" ([117], p. 1425). To promote large-scale slum-mapping programs, clear guidelines and continuous political support is necessary, shown by the challenges of implementing, for instance, past slum-mapping programs in Indian cities (RAY; the vision of a slum-free India) [184].

A major bottleneck (besides image costs) is image availability due to frequent cloud cover in tropical cities. However, since the massive increase of VHR sensors, we can expect an improvement of image availability. To further overcome this problem, more $(\mathrm{V}) \mathrm{HR}$ resolution SAR sensors are available (e.g., TerraSAR-X) that penetrate clouds, being suitable for texture analysis of slums [60,89]. Also, LIDAR data have enormous potential for object extraction with their capability of extracting building heights [185], a relevant indicator for slum mapping [4]. Furthermore, drones (UAVs) are able to fly below clouds to capture settlement details [186], but to cover entire cities would be computational challenging, in addition to the inevitable privacy issues. In addition, other image data sources have potential, e.g., night-light images. Unfortunately, the resolution of sensors like OLS is too low to map detailed inner urban night-light variations. On a metropolitan scale, researchers successfully correlated poverty rates with observed night-time lights (e.g., [187]). Alternative image sources for global slum mapping are, for instance, GE images that allow working with VHR imagery free of charge (democratizing data access), where texture-based image analysis showed promising accuracies [98]. To increase the classification accuracy, several studies have proposed the use of auxiliary data, such as the utility of DSM for built-up or roof extraction [153] or the usage of VGI (volunteered geographic information) [69].

\subsection{Systematic Conceptualization of Slums: Methods and Slum Characteristics}

Regarding the transferability and robustness of OBIA-based methods (across different data and locations), locally developed rule sets have their limitations, compared to the better performance of texture-based or machine-learning algorithms [188]. Furthermore, the latter have the capacity to 
deal with multilayer inputs of spectral, texture or spatial-physical indicators (e.g., [46]). However, machine-learning algorithms (both parametric and non-parametric) mostly employ per-pixel classifiers. Only a few examples extracted area-based layers (e.g., via segments) [188], which would be more relevant for slum mapping towards informing pro-poor policies. Thus, besides setting up a well-structured conceptual framework in form of a slum ontology [71] and developing a consistent framework for assessing the transferability and robustness of slum extraction methods [23], the advantages of both methods-OBIA and machine learning-need be combined.

One major dilemma when assessing the performance of slum-mapping methods is access to reference data. In general, studies use ground truth data (collected in the field) (e.g., [45]), expert delineations (e.g., [82]), or available municipal data sets (e.g., [183]). All data sets have the inherent dilemma of "what is a slum," as slum definitions vary between and within countries but even within a city, and different institutions can have different slum definitions and therefore slum maps (e.g., in Jakarta [189]). These uncertainties have a negative impact on classification accuracies [158], and reduces the comparability of the performance of different slum-mapping methods. In Sections 5 and 7 the role of systematically selected image-based proxies (e.g., in form of a slum ontology) for methodological advances in slum mapping has been stressed. Therefore, a more systematic exploration of potential proxies to describe differences within slums and slums versus formal areas is needed. A first starting point is the relation between classical visual image interpretation elements [116] and physical characteristics of slums. This would allow developing systematic rules for OBIA or training machine-learning approaches similar to how human interpreters recognize slums. An overview of proxies is presented in Table 8 .

Table 8. Overview of successfully documented image-based proxies (indicators).

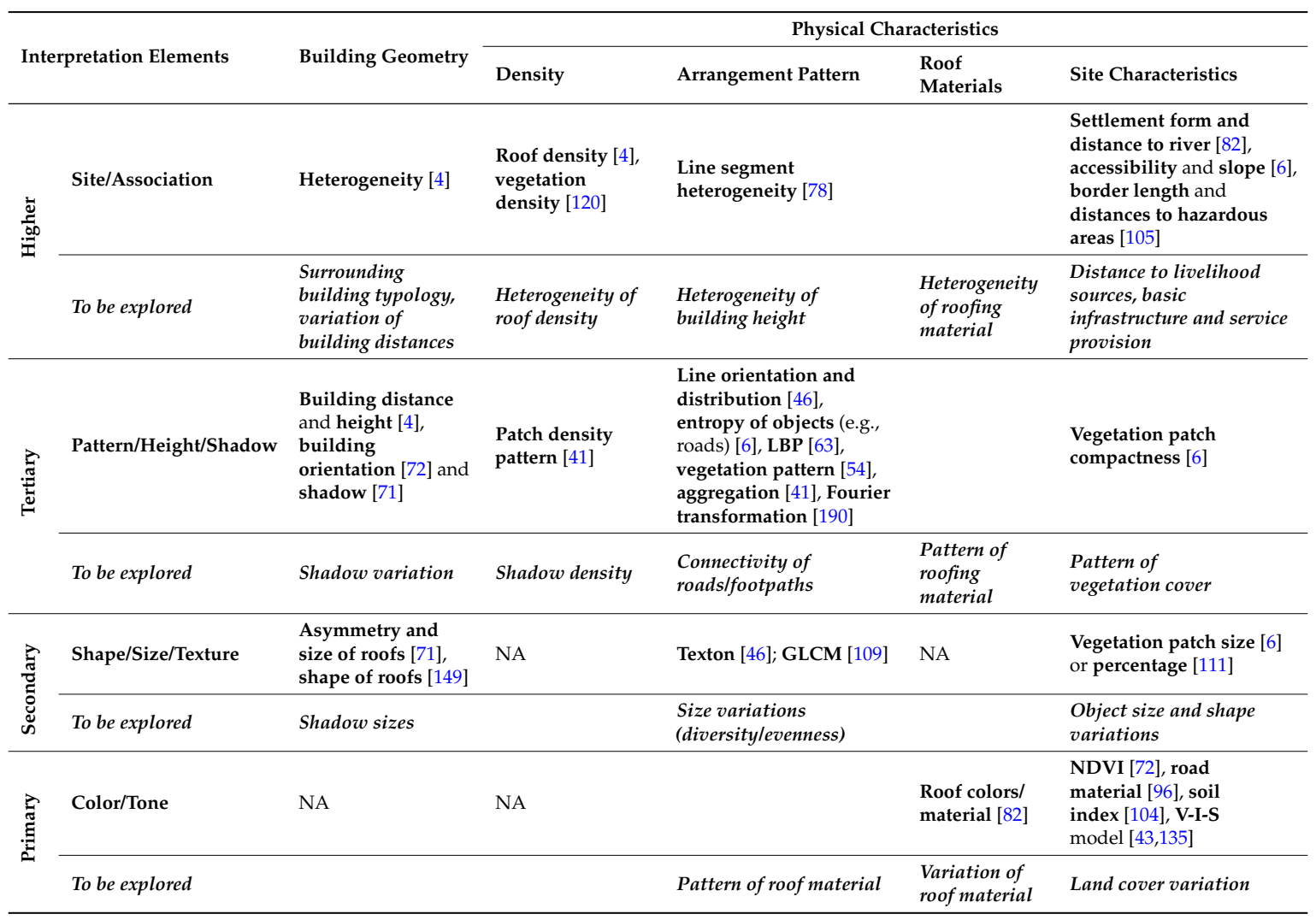

In the literature, many interpretation elements have been employed-simple (primary) ones based on color, or complex (tertiary and higher) ones, based on pattern or site. However, many potentially interesting combinations have not been systematically explored (Table 8), e.g., homogeneity of 
roofing material at settlement level. Building height has only been used in an explorative study [4]. Other site/association-related proxies have only been used in a few OBIA studies (e.g., [78,82]). Promising proxies relate to distance to livelihood opportunities and services, road features (e.g., available from OSM) or general line features and their orientation and pattern. For example, we know that lines in slums are generally much more irregular and heterogeneous in orientation compared to formal settlements [78]. Furthermore, the analysis of heterogeneity (versus homogeneity) and patterns of density, roof materials, shadow, vegetation, and other land cover types could provide promising proxies. Thus a more systematic inclusion of all levels of interpretation elements will be important to improve slum extraction approaches. To avoid high dimensionality of large proxy sets, automatized feature selection will be the road forward [191], allowing the selection of the most relevant features (indicators) while excluding redundant ones.

Presently, we know too little about the global diversity of slums and how to capture this diversity by robust image-based proxies. Thus, a more systematic exploration of potential proxies is required for the development of a global slum inventory. Besides the establishment of a global slum inventory, regular monitoring systems at local level are necessary for the detection of changes but also as an instrument to monitor policy implementation or to protect slum dwellers against illegal evictions.

\section{Conclusions}

In this review, we identified the variety of methodological advances in slum-mapping studies that are relevant for developing a global slum inventory. The reviewed literature shows that the current geographic knowledge on slum characteristics is rather limited. This knowledge needs to be extended to cover the main urban regions in the Global South, especially where urban growth rates and poverty levels are high. Specifically, more comparative studies on proxies are needed across the globe, using a systematic depiction of established slum characteristics (i.e., building geometry, density, pattern, roof material and site characteristics) versus image (interpretation) elements for the development of robust image-based proxies. This also requires a clear conceptual frame to assess their transferability and robustness. The same is required for methodologies. On the basis of the reported accuracies and the ability to process larger data and indicator sets, the most promising methods for a global slum inventory use machine-learning approaches. Several important recommendations for future methodological developments are: (1) include better contextual properties (larger neighborhoods); (2) avoid pixel-based approaches; (3) employ scalable aggregation levels that allow the mapping of smaller slum pockets as well as larger slum areas; (4) include more complex interpretation elements (site and association) and proxies based on ancillary data; and (5) examine the impact of different sensor characteristics on classification accuracies.

For OBIA, extracting object-level information on roofs or roads, often required for counting dwellings or estimating population, the availability of VHR imagery in the range of $30 \mathrm{~cm}$ might open up new avenues, in particular for very high-density slums in Asian cities. For the further development of OBIA approaches that are fit for city or settlement-level information extraction, the important recommendations and considerations are: (1) select suitable sensors for the local context; (2) systematic slum characterization should be translated into robust and transferable rule sets; (3) include readily available ancillary data in the classification process; (4) link image-derived products with socioeconomic data.

Locally feasible and quick monitoring approaches could rely on both, OBIA or machine learning, but also single indicator approaches (e.g., GLCM or lacunarity) have the potential to capture quickly the location and extent of slum areas in support of pro-poor policy implementations. Therefore, capturing the local slum morphology with the most suitable indicator(s) transferable to imagery of different sensors or different years is crucial. Nevertheless, a global slum inventory must acknowledge the diversity of slums within and between cities. Therefore, besides the mapping of slums, the identification of contextual slum typologies is an important research direction; such information will allow the combination of image-based information with socioeconomic characteristics, which may 
ultimately lead to a better targeting of pro-poor policy interventions. Finally, the information gap and access to data between the Global South and North needs to be better bridged by making data and tools globally accessible to local actors with appropriate attention for capacity building to ensure proper understanding and application.

Acknowledgments: The authors prepared this review as part of their duties at their respective universities. No external financial support was received to prepare the review. The costs for publishing in open access were paid by the Open Access fund Grant of the University of Twente.

Author Contributions: Monika Kuffer analyzed the reviewed publications and wrote the majority of the paper. Karin Pfeffer and Richard Sliuzas supported the developing of the structure of the paper and revised the paper over several rounds. Karin Pfeffer contributed many conceptual, practical ideas and examples in particular from Asian countries. Richard Sliuzas contributed examples from SSA countries and supported the organization of the paper.

Conflicts of Interest: The authors declare no conflict of interest.

\section{Abbreviations}

The following abbreviations are used in this manuscript:

$\begin{array}{ll}\text { RS } & \text { Remote sensing } \\ \text { VHR } & \text { Very high resolution } \\ \text { OBIA } & \text { Object-based image analysis } \\ \text { SSA } & \text { Sub-Saharan Africa } \\ \text { GE } & \text { Google Earth } \\ \text { DSM } & \text { Digital surface model } \\ \text { LBP } & \text { Local binary pattern } \\ \text { OSM } & \text { Open street map }\end{array}$

\section{References}

1. UN-Habitat. Informal Settlements; UN-Habitat: New York, NY, USA, 2015; pp. 1-8.

2. UN-Habitat. The Challenge of Slums: Global Report on Human Settlements 2003; Earthscan Publications Ltd.: London, UK; Sterling, VA, USA, 2003.

3. Veljanovski, T.; Kanjir, U.; Pehani, P.; Oštir, K.; Kovačič, P. Object-based image analysis of VHR satellite imagery for population estimation in informal settlement Kibera-Nairobi, Kenya. In Remote Sensing-Applications; Escalante, B., Ed.; InTech: Rijeka, Croatia, 2012; pp. 407-434.

4. Taubenböck, H.; Kraff, N.J. The physical face of slums: A structural comparison of slums in Mumbai, India, based on remotely sensed data. J. Hous. Built Environ. 2014, 29, 15-38. [CrossRef]

5. Kohli, D.; Sliuzas, R.V.; Kerle, N.; Stein, A. An ontology of slums for image-based classification. Comput. Environ. Urban Syst. 2012, 36, 154-163. [CrossRef]

6. Owen, K.K.; Wong, D.W. An approach to differentiate informal settlements using spectral, texture, geomorphology and road accessibility metrics. Appl. Geogr. 2013, 38, 107-118. [CrossRef]

7. Hofmann, P.; Strobl, J.; Blaschke, T.; Kux, H. Detecting informal settlements from QuickBird data in Rio de Janeiro using an object based approach. In Object-Based Image Analysis; Blaschke, T., Lang, S., Hay, G., Eds.; Springer: Berlin \Heidelberg, Germany, 2008; pp. 531-553.

8. Taubenböck, H.; Kraff, N.J. Das globale Gesicht urbaner Armut? Siedlungsstrukturen in Slums. In Globale Urbanisierung; Taubenböck, H., Wurm, M., Esch, T., Dech, S., Eds.; Springer: Berlin, Germany; Heidelberg, Germany, 2015; pp. 107-119.

9. Wolvers, A.; Tappe, O.; Salverda, T.; Schwarz, T. Concepts of the Global South-Voices from around the World Global South Studies Center; University of Cologne: Cologne, Germany, 2015.

10. Kit, O.; Lüdeke, M. Automated detection of slum area change in Hyderabad, India using multitemporal satellite imagery. ISPRS J. Photogramm. Remote Sens. 2013, 83, 130-137. [CrossRef]

11. Batson, D.E. Black spots are no treasure island: Land tenure and property rights in megacities. In Understanding Megacities with the Reconnaissance, Surveillance, and Intelligence Paradigm; Ehlschlaeger, C., Ed.; Topical Strategic Multi-Layer Assessment (SMA) and U.S. Army Engineer Research Development Center (ERDC) White Papers in Support of National Security Challenges: Vicksburg, MS, USA, 2014; pp. 34-47.

12. UN-Habitat. Streets as Public Spaces and Drivers of Urban Prosperity; UN-Habitat: Nairobi, Kenya, 2013. 
13. Arimah, B.C. The face of urban poverty: Explaining the prevalence of slums in developing countries. In Urbanization and Development: Multidisciplinary Perspectives; Beall, J., Guha-Khasnobis, B., Kanbur, R., Eds.; Oxford Scholarship Online: Oxford, UK, 2011; pp. 143-164.

14. Kundu, A. Provision of tenurial security for the urban poor in Delhi: Recent trends and future perspectives. Habitat Int. 2004, 28, 259-274. [CrossRef]

15. Peattie, L.R. Some second thoughts on sites-and-services. Habitat Int. 1982, 6, 131-139. [CrossRef]

16. Pugh, C. The theory and practice of housing sector development for developing countries, $1950-99$. Hous. Stud. 2001, 16, 399-423. [CrossRef]

17. Patel, S.; Sliuzas, R.; Mathur, N. The risk of impoverishment in urban development-induced displacement and resettlement in Ahmedabad. Environ. Urban. 2015, 27, 231-256. [CrossRef]

18. Coelho, K.; Raman, N. Salvaging and scapegoating: Slum eviction on Chennai's waterways. Econ. Political Wkly. 2010, 45, 19-21.

19. Viratkapan, V.; Perera, R. Slum relocation projects in Bangkok: What has contributed to their success or failure? Habitat Int. 2006, 30, 157-174. [CrossRef]

20. Perlman, J. Favela: Four Decades of Living on the Edge in Rio de Janeiro; Oxford University Press: New York, NY, USA, 2010.

21. Abbott, J. The use of GIS in informal settlement upgrading: Its role and impact on the community and on local government. Habitat Int. 2003, 27, 575-593. [CrossRef]

22. Pugh, C. Squatter settlements: Their sustainability, architectural contributions, and socio-economic roles. Cities 2000, 17, 325-337. [CrossRef]

23. Hofmann, P. Defining robustness measures for OBIA framework: A case study for detecting informal settlements. In Global Urban Monitoring and Assessment through Earth Observation; Weng, Q., Ed.; CRC Press: Boca Raton, FL, USA, 2014; pp. 303-324.

24. Abbott, J. An analysis of informal settlement upgrading and critique of existing methodological approaches. Habitat Int. 2002, 26, 303-315. [CrossRef]

25. Olthuis, K.; Benni, J.; Eichwede, K.; Zevenbergen, C. Slum upgrading: Assessing the importance of location and a plea for a spatial approach. Habitat Int. 2015, 50, 270-288. [CrossRef]

26. UN-Habitat. State of the World's Cities 2012/2013: Prosperity of Cities; Routledge: New York, NY, USA, 2013.

27. UN-Habitat. State of the World's Cities 2010/2011; Earthscan: London, UK; Sterling, VA, USA, 2008.

28. Cobbett, W. How cities can get rid of slums by supporting them. Informal City Dialogues, 22 April 2013.

29. Patel, S.; Baptist, C. Editorial: Documenting by the undocumented. Environ. Urban. 2012, 24, 3-12. [CrossRef]

30. Patino, J.E.; Duque, J.C. A review of regional science applications of satellite remote sensing in urban settings. Comput. Environ. Urban Syst. 2013, 37, 1-17. [CrossRef]

31. Taubenbock, H.; Wurm, M.; Setiadi, N.; Gebert, N.; Roth, A.; Strunz, G.; Birkmann, J.; Dech, S. Integrating remote sensing and social science. In Proceedings of the IEEE Joint Urban Remote Sensing Event, Shanghai, China, 20-22 May 2009; pp. 1-7.

32. Netzband, M.; Rahman, A. Physical characterisation of deprivation in cities: How can remote sensing help to profile poverty (slum dwellers) in the megacity of Delhi/India? In Proceedings of the IEEE Joint Urban Remote Sensing Event, Shanghai, China, 20-22 May 2009; pp. 1-5.

33. Engstrom, R.; Ofiesh, C.; Rain, D.; Jewell, H.; Weeks, J.R. Defining neighborhood boundaries for urban health research in developing countries: A case study of Accra, Ghana. J. Maps 2013, 9, 36-42. [CrossRef] [PubMed]

34. Beukes, A. Making the Invisible Visible: Generating Data on 'Slums' at Local, City and Global Scales; International Institute for Environment and Development: London, UK, 2015.

35. Joshi, P.; Sen, S.; Hobson, J. Experiences with surveying and mapping Pune and Sangli slums on a geographical information system (GIS). Environ. Urban. 2002, 14, 225-240. [CrossRef]

36. Sliuzas, R.V.; Mboup, G.; de Sherbinin, A. Report of the Expert Group Meeting on Slum Identification and Mapping; CIESIN, UN-Habitat, ITC: Enschede, The Netherlands, 2008.

37. Sliuzas, R.; Kuffer, M.; Masser, I. The spatial and temporal nature of urban objects. In Remote Sensing of Urban and Suburban Areas; Rashed, T., Jürgens, C., Eds.; Springer: Dordrecht, The Netherlands, 2010; Volume 10, pp. 67-84.

38. Owen, K.K.; Wong, D.W. Exploring structural differences between rural and urban informal settlements from imagery: The basureros of Cobán. Geocarto Int. 2013, 28, 562-581. [CrossRef] 
39. Stasolla, M.; Gamba, P. Exploiting spatial patterns for informal settlement detection in arid environments using optical spaceborne data. Int. Arch. Photogramm. Remote Sens. Spat. Inf. Sci. 2007, 36, 31-36.

40. Williams, N.; Quincey, D.; Stillwell, J. Automatic classification of roof objects from aerial imagery of informal settlements in Johannesburg. Appl. Spat. Anal. 2015. [CrossRef]

41. Kuffer, M.; Barros, J.; Sliuzas, R. The development of a morphological unplanned settlement index using very-high-resolution (VHR) imagery. Comput. Environ. Urban Syst. 2014, 48, 138-152. [CrossRef]

42. Liu, X.H.; Clarke, K.; Herold, M. Population density and image texture: A comparison study. Photogramm. Eng. Remote Sens. 2006, 72, 187-196. [CrossRef]

43. Weeks, J.R.; Hill, A.; Stow, D.A.; Getis, A.; Fugate, D. Can we spot a neighborhood from the air? Defining neighborhood structure in Accra, Ghana. GeoJournal 2007, 69, 9-22. [CrossRef] [PubMed]

44. Gueguen, L. Classifying compound structures in satellite images: A compressed representation for fast queries. IEEE Trans. Geosci. Remote Sens. 2015, 53, 1803-1818. [CrossRef]

45. Kit, O.; Lüdeke, M.; Reckien, D. Texture-based identification of urban slums in Hyderabad, India using remote sensing data. Appl. Geogr. 2012, 32, 660-667. [CrossRef]

46. Graesser, J.; Cheriyadat, A.; Vatsavai, R.R.; Chandola, V.; Long, J.; Bright, E. Image based characterization of formal and informal neighborhoods in an urban landscape. IEEE J. Sel. Top. Appl. Earth Observ. Remote Sens. 2012, 5, 1164-1176. [CrossRef]

47. Karantzalos, K. Recent advances on 2D and 3D change detection in urban environments from remote sensing data. In Computational Approaches for Urban Environments; Helbich, M., Jokar Arsanjani, J., Leitner, M., Eds.; Springer International Publishing: Cham, Switzerland; Heidelberg, Germany; New York, NY, USA; Dordrecht, The Netherlands; London, UK, 2015; Volume 13, pp. 237-272.

48. Hofmann, P.; Taubenböck, H.; Werthmann, C. Monitoring and modelling of informal settlements-A review on recent developments and challenges. In Proceedings of the IEEE Joint Urban Remote Sensing Event (JURSE), Lausanne, Switzerland, 30 March-1 April 2015; pp. 1-4.

49. Esch, T.; Thiel, M.; Schenk, A.; Roth, A.; Müller, A. Delineation of urban footprints from TerraSAR-X data by analyzing speckle characteristics and intensity information. IEEE Trans. Geosci. Remote Sens. 2010, 48, 905-916. [CrossRef]

50. Esch, T.; Taubenbock, H.; Roth, A.; Heldens, W.; Felbier, A.; Thiel, M.; Schmidt, M.; Muller, A.; Dech, S. TanDEM-X mission-new perspectives for the inventory and monitoring of global settlement patterns. J.Appl. Remote Sens. 2012, 6. [CrossRef]

51. Pesaresi, M.; Guo, H.D.; Blaes, X.; Ehrlich, D.; Ferri, S.; Gueguen, L.; Halkia, M.; Kauffmann, M.; Kemper, T.; Lu, L.L.; et al. A global human settlement layer from optical HR/VHR RS data: Concept and first results. IEEE J. Sel. Top. Appl. Earth Observ. Remote Sens. 2013, 6, 2102-2131. [CrossRef]

52. Gamba, P.; Du, P.J.; Juergens, C.; Maktav, D. Foreword to the special issue on “human settlements: A global remote sensing challenge". IEEE J. Sel. Top. Appl. Earth Observ. Remote Sens. 2011, 4, 5-7. [CrossRef]

53. Vaz, L.F.; Berenstein, J.P. Morphological diversity in the squatter settlements of Rio de Janeiro. In Suburban Form: An International Perspective; Stanilov, K., Scheer, B., Eds.; Routledge: New York, NY, USA, 2004; pp. 61-72.

54. Baud, I.; Kuffer, M.; Pfeffer, K.; Sliuzas, R.V.; Karuppannan, S. Understanding heterogeneity in metropolitan India: The added value of remote sensing data for analyzing sub-standard residential areas. Int. J. Appl. Earth Obs. Geoinf. 2010, 12, 359-374. [CrossRef]

55. Aminipouri, M.; Sliuzas, R.V.; Kuffer, M. Object oriented analysis of very high resolution orthophotos for estimating the population of slum areas, case of Dar Es Salaam, Tanzania. In Proceedings of the ISPRS Conference: High-Resolution Earth Imaging for Geospatial Information: ISPRS XXXVIII 1-4-7/WS, Hannover, Germany, 2-5 June 2009.

56. Asmat, A.; Zamzami, S.Z. Automated house detection and delineation using optical remote sensing technology for informal human settlement. Procedia Soc. Behav. Sci. 2012, 36, 650-658. [CrossRef]

57. Barros Filho, M.; Sobreira, F. Assessing Texture Pattern in slum Across Scales an Unsupervised Approach; CASA Working Papers Series; Centre for Advanced Spatial Analysis (UCL): London, UK, 2005; Volume 87.

58. Biggs, T.W.; Anderson, W.G.; Pombo, O.A. Concrete and poverty, vegetation and wealth? A counter example from remote sensing of socioeconomic indicators on the U.S.-Mexico border. Prof. Geogr. 2015, 67, 166-179. [CrossRef] 
59. Dell'Acqua, F.; Stasolla, M.; Gamba, P. Unstructured human settlement mapping with SAR sensors. In Proceedings of the IEEE Geoscience and Remote Sensing Symposium, IGARSS 2006, New York, NY, USA, 31 July-4 August 2006; pp. 3619-3622.

60. Dell'Acqua, F.; Lisini, G.; Gamba, P. Spatial information to discriminate between slums and other urban settlements in TerraSAR-X image. In Proceedings of the 4th TerraSAR-X Science Team Meeting, Oberpfaffenhofen, Germany, 14-16 February 2011.

61. Duque, J.C.; Patino, J.E.; Ruiz, L.A.; Pardo-Pascual, J.E. Measuring intra-urban poverty using land cover and texture metrics derived from remote sensing data. Landsc. Urban Plan. 2015, 135, 11-21. [CrossRef]

62. Eckert, S. Urban expansion and its impact on urban agriculture-remote sensing based change analysis of Kizinga and Mzinga valley-Dar Es Salaam, Tanzania. EARSeL eProc. 2010, 10, 46-55.

63. Ella, L.P.A.; Van Den Bergh, F.; Van Wyk, B.J.; Van Wyk, M.A. A comparison of texture feature algorithms for urban settlement classification. In Proceedings of the IEEE International Geoscience and Remote Sensing Symposium (IGARSS), Boston, MA, USA, 7-11 July 2008; Volume 3, pp. III1308-III1311.

64. Engstrom, R.; Sandborn, A.; Yu, Q.; Burgdorfer, J.; Stow, D.; Weeks, J.; Graesser, J. Mapping slums using spatial features in Accra, Ghana. In Proceedings of the 2015 IEEE Joint Urban Remote Sensing Event (JURSE), Lausanne, Switzerland, 30 March-1 April 2015; pp. 1-4.

65. Galeon, F. Estimation of Population in informal settlement communities using high resolution satellite image. In Proceedings of the XXI ISPRS Congress, Commission IV, Citeseer, Beijing, China, 3-11 July 2008; Volume 37, pp. 1377-1381.

66. Gamba, P.; Dell'Acqua, F.; Trianni, G. Satellite SAR and Human settlement detection. In Proceedings of the 2007 Urban Remote Sensing Joint Event, Paris, France, 11-13 April 2007.

67. Giada, S.; De Groeve, T.; Ehrlich, D.; Soille, P. Information extraction from very high resolution satellite imagery over Lukole refugee camp, Tanzania. Int. J. Remote Sens. 2003, 24, 4251-4266. [CrossRef]

68. Gruebner, O.; Sachs, J.; Nockert, A.; Frings, M.; Khan, M.H.; Lakes, T.; Hostert, P. Mapping the slums of Dhaka from 2006 to 2010. Dataset Pap. Sci. 2014, 2014, 1-7. [CrossRef]

69. Gunter, A.W. Getting it for free: Using Google Earth ${ }^{\mathrm{TM}}$ and Ilwis to map squatter settlements in Johannesburg. In Proceedings of the IEEE International Geoscience and Remote Sensing Symposium (IGARSS), Cape Town, South Africa, 12-17 July 2009; Volume 3, pp. III388-III391.

70. Hassan, A.A.M. Change in the urban spatial structure of the Greater Cairo metropolitan area, Egypt. Int. Arch. Photogramm. Remote Sens. Spat. Inf. Sci. 2011, 38, 133-136. [CrossRef]

71. Hofmann, P.; Blaschke, T.; Strobl, J. Quantifying the robustness of fuzzy rule sets in object-based image analysis. Int. J. Remote Sens. 2011, 32, 7359-7381. [CrossRef]

72. Huang, X.; Liu, H.; Zhang, L. Spatiotemporal detection and analysis of urban villages in mega city regions of China using high-resolution remotely sensed imagery. IEEE Trans. Geosci. Remote Sens. 2015, 53, 3639-3657. [CrossRef]

73. Hurskainen, P.; Pellikka, P. Change detection of informal settlements using multi-temporal aerial photographs-the case of Voi, SE-Kenya. In Proceedings of the 5th African Association of Remote Sensing of the Environment Conference, Nairobi, Kenya, 18-21 October 2004.

74. Iannelli, G.C.; Lisini, G.; Dell'Acqua, F.; Feitosa, R.Q.; da Costa, G.A.; Gamba, P. Urban area extent extraction in spaceborne HR and VHR data using multi-resolution features. Sensors 2014, 14, 18337-18352. [CrossRef] [PubMed]

75. Jain, S. Use of Ikonos satellite data to identify informal settlements in Dehradun, India. Int. J. Remote Sens. 2007, 28, 3227-3233. [CrossRef]

76. Kemper, T.; Jenerowicz, M.; Pesaresi, M.; Soille, P. Enumeration of dwellings in Darfur camps from GeoEye-1 satellite images using mathematical morphology. IEEE J. Sel. Top. Appl. Earth Observ. Remote Sens. 2011, 4, 8-15. [CrossRef]

77. Kemper, T.; Mudau, N.; Mangara, P.; Pesaresi, M. Towards an automated monitoring of human settlements in South Africa using high resolution SPOT satellite imagery. In Proceedings of the 36th International Symposium on Remote Sensing of Environment, Berlin, Germany, 11-15 May 2015; Volume XL-7/W3, pp. 1389-1394.

78. Khelifa, D.; Mimoun, M. Object-based image analysis and data mining for building ontology of informal settlements. In Proceedings of the Image and Signal Processing for Remote Sensing XVIII, Edinburgh, UK, 8 November 2012; Volume 8537. 
79. Kleynhans, W.; Salmon, B.P. Detecting settlement expansion using hyper-temporal SAR time-series. In Proceedings of the IEEE International Geoscience and Remote Sensing Symposium (IGARSS), Quebec City, QC, Canada, 13-18 July 2014; pp. 1152-1155.

80. Kleynhans, W.; Salmon, B.P.; Wessels, K.J. A novel spatio-temporal change detection approach using hyper-temporal satellite data. In Proceedings of the IEEE Geoscience and Remote Sensing Symposium (IGARSS), Quebec City, QC, Canada, 2014; pp. 4208-4211.

81. Kleynhans, W.; Salmon, B.P.; Olivier, J.C. Detecting settlement expansion in South Africa using a hyper-temporal SAR change detection approach. Int. J. Appl. Earth Obs. Geoinf. 2015, 42, 142-149. [CrossRef]

82. Kohli, D.; Warwadekar, P.; Kerle, N.; Sliuzas, R.; Stein, A. Transferability of object-oriented image analysis methods for slum identification. Remote Sens. 2013, 5, 4209-4228. [CrossRef]

83. Kohli, D. Spatial metrics and image texture for slum detection. In Proceedings of the 14th N-AERUS/GISDECO Conference, N-AERUS XIV, Enschede, The Netherlands, 12-14 September 2013.

84. Krishna, A.; Sriram, M.; Prakash, P. Slum types and adaptation strategies: Identifying policy-relevant differences in Bangalore. Environ. Urban. 2014, 26, 568-585. [CrossRef]

85. Kuffer, M.; Pfeffer, K.; Baud, I.S.A.; Sliuzas, R.V. Analysing sub-standard areas using high resolution remote (VHR) sensing imagery. In Proceedings of the 14th N-AERUS/GISDECO Conference, Enschede, The Netherlands, 12-14 September 2013.

86. Kuffer, M.; Sliuzas, R.; Pfeffer, K.; Baud, I. The utility of the co-occurrence matrix to extract slum areas from VHR imagery. In Proceedings of the IEEE Joint Urban Remote Sensing Event (JURSE), Lausanne, Switzerland, 30 March-1 April 2015; pp. 1-4.

87. Li, J.; Li, Y.; Chapman, M.A.; Rüther, H. Small format digital imaging for informal settlement mapping. Photogramm. Eng. Remote Sens. 2005, 71, 435-442. [CrossRef]

88. Lippitt, C.D.; Stow, D.A.; Toure, S.; Vejraska, M. Delineation and classification of urban neighborhoods of Accra, Ghana, from Quickbird imagery: Manual vs. semi-automated approaches. In Spatial Inequalities; Weeks, J.R., Hill, A.G., Stoler, J., Eds.; Springer Netherlands: Dordrecht, The Netherlands, 2013; Volume 110, pp. 57-71.

89. Lisini, G.; Gamba, P.; Dell'Acqua, F. A novel extension of the anisotropic rotation-invariant built-up presence index to SAR data. Eur. J. Remote Sens. 2012, 45, 189-199. [CrossRef]

90. Marghany, M.; van Genderen, J. Three-dimensional slum urban reconstruction in Envisat and Google Earth Egypt. In Proceedings of the IOP Conference Series: Earth and Environmental Science, Sarawak, Malaysia, 26-29 August 2014; Volume 18.

91. Mayunga, S.D.; Coleman, D.J.; Zhang, Y. A semi-automated approach for extracting buildings from QuickBird imagery applied to informal settlement mapping. Int. J. Remote Sens. 2007, 28, 2343-2357. [CrossRef]

92. Montana, L.; Lance, P.M.; Mankoff, C.; Speizer, I.S.; Guilkey, D. Using satellite data to delineate slum and non-slum sample domains for an urban population survey in Uttar Pradesh, India. Spat. Demogr. 2015. [CrossRef] [PubMed]

93. Munyati, C.; Motholo, G.L. Inferring urban household socio-economic conditions in Mafikeng, South Africa, using high spatial resolution satellite imagery. Urban Plan. Trans. Res. 2014, 2, 57-71. [CrossRef]

94. Niebergall, S.; Loew, A.; Mauser, W. Integrative assessment of informal settlements using VHR remote sensing data-The Delhi case study. IEEE J. Sel. Top. Appl. Earth Observ. Remote Sens. 2008, 1, $193-205$. [CrossRef]

95. Nobrega, R.A.A.; O'Hara, C.G.; Quintanilha, J.A. An object-based approach to detect road features for informal settlements near Sao Paulo, Brazil. In Object-Based Image Analysis; Blaschke, T., Lang, S., Hay, G.J., Eds.; Springer: Berlin, Germany; Heidelberg, Germany, 2008; pp. 589-607.

96. Novack, T.; Kux, H.J.H. Urban land cover and land use classification of an informal settlement area using the open-source knowledge-based system InterIMAGE. J. Spat. Sci. 2010, 55, 23-41. [CrossRef]

97. Oleire-Oltmanns, S.; Coenradie, B.; Kleinschmit, B. An object-based classification approach for mapping migrant housing in the mega-urban area of the Pearl River Delta (China). Remote Sens. 2011, 3, 1710-1723. [CrossRef]

98. Praptono, N.H.; Sirait, P.; Fanany, M.I.; Arymurthy, A.M. An automatic detection method for high density slums based on regularity pattern of housing using Gabor filter and GINI index. In Proceedings of the IEEE Advanced Computer Science and Information Systems (ICACSIS), Bali, Indonesia, 28-29 September 2013; pp. 347-351. 
99. Radnaabazar, G.; Kuffer, M.; Hofstee, P. Monitoring the development of informal settlements in Ulanbaatar, Mongolia. In Proceedings of CORP2004, Vienna University of Technology, Vienna, Austria, 25-27 February 2004; pp. 25-28.

100. Rhinane, H.; Hilali, A.; Berrada, A.; Hakdaoui, M. Detecting slums from SPOT data in Casablanca Morocco using an object based approach. J. Geogr. Inf. Syst. 2011, 3, 217-224. [CrossRef]

101. Ribeiro, B.M.G. Mapping informal settlements using WorldView-2 imagery and C4.5 decision tree classifier. In Proceedings of the IEEE Joint Urban Remote Sensing Event (JURSE), Lausanne, Switzerland, 30 March-1 April 2015.

102. Rüther, H.; Martine, H.M.; Mtalo, E.G. Application of snakes and dynamic programming optimisation technique in modeling of buildings in informal settlement areas. ISPRS J. Photogramm. Remote Sens. 2002, 56, 269-282. [CrossRef]

103. Sahriman, N.; Abiden, M.Z.Z.; Rasam, A.R.A.; Samad, A.M.; Md Tarmizi, N. Urban poverty area identification using high resolution satellite imagery: A preliminary correlation study. In Proceedings of the 2013 IEEE International Conference on Control System, Computing and Engineering (ICCSCE), Penang, Malaysia, 29 November-1 December 2013; pp. 430-434.

104. Schöpfer, E.; Tiede, D.; Lang, S.; Zeil, P. Damage assessment in townships using VHSR data; The effect of operation Murambatsvina/restore order in Harare, Zimbabwe. In Proceedings of the IEEE Urban Remote Sensing Joint Event, Paris, France, 11-13 April 2007; pp. 1-5.

105. Shekhar, S. Detecting slums from Quick Bird data in Pune using an object oriented approach. Int. Arch. Photogramm. Remote Sens. Spat. Inf. Sci. 2012, 39, 519-524. [CrossRef]

106. Sliuzas, R.V.; Kerle, N.; Kuffer, M. Object-oriented mapping of urban poverty and deprivation. In Proceedings of the 4th EARSeL Workshop on Remote Sensing for developing Countries in Conjunction with GISDECO 8/European Association of Remote Sensing Laboratories (EARSeL), Istanbul, Turkey, 4-7 June 2008.

107. Stasolla, M.; Gamba, P. Spatial indexes for the extraction of formal and informal human settlements from high-resolution SAR images. IEEE J. Sel. Top. Appl. Earth Observ. Remote Sens. 2008, 1, 98-106. [CrossRef]

108. Stasolla, M.; Gamba, P. Mapping informal settlements with a GUS land use legend. In Proceedings of the IEEE International Geoscience and Remote Sensing Symposium (IGARSS), New York, NY, USA, 31 July-4 August 2006; pp. 3786-3789.

109. Stasolla, M.; Gamba, P. Humanitarian aids using satellite technology. In Space Technologies for the Benefit of Human Society and Earth; Olla, P., Ed.; Springer Netherlands: Dordrecht, The Netherlands, 2009; pp. 431-451.

110. Stoler, J.; Daniels, D.; Weeks, J.R.; Stow, D.A.; Coulter, L.L.; Finch, B.K. Assessing the utility of satellite imagery with differing spatial resolutions for deriving proxy measures of slum presence in Accra, Ghana. GISci. Remote Sens. 2012, 49, 31-52. [CrossRef] [PubMed]

111. Stow, D.A.; Lippitt, C.D.; Weeks, J.R. Geographic object-based delineation of neighborhoods of Accra, Ghana using QuickBird satellite imagery. Photogramm. Eng. Remote Sens. 2010, 76, 907-914. [CrossRef]

112. Sur, U.; Jain, S.; Sokhi, B.S. Identification and mapping of slum environment using IKONOS satellite data: A case study of Dehradun, India. In Proceedings of the Map India 2004 Conference, New Delhi, India, 28-30 January 2004.

113. Tarmizi, N.M.; Shahriman, N.; Maarof, I.; Samad, A.M. A concept of urban poverty area identification using spatial correlation studies on high resolution satellite imagery. In Proceedings of the FIG Congress 2014: Engaging the Challenges-Enhancing the Relevance, Kuala Lumpur, Malaysia, 16-21 June 2014.

114. Taubenböck, H.; Post, J.; Kiefl, R.; Roth, A.; Ismail, F.A.; Strunz, G.; Dech, S. Risk and vulnerability assessment to tsunami hazard using very high resolution satellite data: The case study of Padang, Indonesia. In EARSeL: Remote Sensing—New Challenges of High Resolution; Jürgens, C., Ed.; Bochum, Germany, 2008; pp. 77-86.

115. Theng, L.B. Automatic building extraction from satellite imagery. Eng. Lett. 2006, 13, 255-259.

116. Vatsavai, R.R. Scalable multi-instance learning approach for mapping the slums of the world. In Proceedings of the 2012 IEEE SC Companion High Performance Computing, Networking, Storage and Analysis (SCC), Salt Lake City, UT, USA, 10-16 November 2012; pp. 833-837.

117. Vatsavai, R.R. Gaussian multiple instance learning approach for mapping the slums of the world using very high resolution imagery. In Proceedings of the 19th ACM SIGKDD International Conference on Knowledge Discovery and Data Mining, Chicago, IL, USA, 11-14 August 2013; pp. 1419-1426. 
118. Verzosa, L.C.O.; Gonzalez, R.M. Remote sensing, geographic information systems and Shannon's entropy: Measuring urban sprawl in a mountainous environment. Int. Arch. Photogramm. Remote Sens. Spat. Inf. Sci. 2010, 38, 269-274.

119. Ward, P.M.; Peters, P.A. Self-help housing and informal homesteading in peri-urban America: Settlement identification using digital imagery and GIS. Habitat Int. 2007, 31, 205-218. [CrossRef]

120. Weeks, J.R.; Getis, A.; Stow, D.A.; Hill, A.G.; Rain, D.; Engstrom, R.; Stoler, J.; Lippitt, C.; Jankowska, M.; Lopez-Carr, A.C.; et al. Connecting the dots between health, poverty, and place in Accra, Ghana. Ann. Assoc. Am. Geogr. 2012, 102, 932-941. [CrossRef] [PubMed]

121. Zubair, O.A.; Ojigi, L.M.; Mbih, R.A. Urbanization: A catalyst for the emergence of squatter settlements and squalor in the vicinities of the federal capital city of Nigeria. J. Sustain. Dev. 2015, 8, 134-148. [CrossRef]

122. Gilbert, A. The return of the slum: Does language matter? Int. J. Urban Reg. Res. 2007, 31, 697-713. [CrossRef]

123. Barros, J.; Sobreira, F. City of Slums: Self-Organisation across Scales; CASA Working Papers Series; Center for Advanced Spatial Analysis (UCL): London, UK, 2002.

124. Leadership Council of the Sustainable Development Solutions Network. Indicators and a Monitoring Framework for the Sustainable Development Goals Launching a Data Revolution for the SDGs; UNSDSN: New York, NY, USA, 2015.

125. Voigt, S.; Schoepfer, E.; Fourie, C.; Mager, A. Towards semi-automated satellite mapping for humanitarian situational awareness. In Proceedings of the IEEE Global Humanitarian Technology Conference (GHTC), San Jose, CA, USA, 10-13 October 2014; pp. 412-416.

126. Shekhar, S. Improving the slum planning through geospatial decision support system. Int. Arch. Photogramm. Remote Sens. Spat. Inf. Sci. 2014, XL-2, 99-105. [CrossRef]

127. Jain, M.; Knieling, J.; Taubenböck, H. Urban transformation in the national capital territory of Delhi, India: The emergence and growth of slums? Habitat Int. 2015, 48, 87-96. [CrossRef]

128. Roy, D.; Lees, M.H.; Palavalli, B.; Pfeffer, K.; Sloot, M.A.P. The emergence of slums: A contemporary view on simulation models. Environ. Model. Softw. 2014, 59, 76-90. [CrossRef]

129. Shuvo, F.K.; Janssen, P. Modelling informal settlements using a hybrid automata approach. In Proceedings of the 18th International Conference on Computer-Aided Architectural Design Research in Asia (Caadria 2013): Open Systems, Hong Kong China; Singapore, Singapore, 15-18 May 2013; pp. 591-600.

130. Augustijn-Beckers, E.-W.; Flacke, J.; Retsios, B. Simulating informal settlement growth in Dar es Salaam, Tanzania: An agent-based housing model. Comput. Environ. Urban Syst. 2011, 35, 93-103. [CrossRef]

131. Dubovyk, O.; Sliuzas, R.V.; Flacke, J. Spatio-temporal modelling of informal settlement development in Sancaktepe district, Istanbul, Turkey. ISPRS J. Photogramm. Remote Sens. 2011, 66, 235-246. [CrossRef]

132. Shekhar, S. Slum modelling by using ontology and geoinformatics: Case study of Gulbarga. Int. J. Geoinf. 2013, 9, 53-60.

133. Taubenböck, H.; Wurm, M. Ich weiß, dass ich nichts weiß-Bevölkerungsschätzung in der Megacity Mumbai. In Globale Urbanisierung: Perspektive aus dem All; Taubenböck, H., Wurm, M., Esch, T., Dech, S., Eds.; Springer Spektrum: Berlin/Heidelberg, Germany, 2015; pp. 171-178.

134. Kit, O.; Lüdeke, M.; Reckien, D. Defining the bull's eye: Satellite imagery-assisted slum population assessment in Hyderabad, India. Urban Geogr. 2013, 34, 413-424. [CrossRef]

135. Stow, D.; Lopez, A.; Lippitt, C.; Hinton, S.; Weeks, J. Object-based classification of residential land use within Accra, Ghana based on QuickBird satellite data. Int. J. Remote Sens. 2007, 28, 5167-5173. [CrossRef] [PubMed]

136. Martinez, I.; Abbott, J. The application of a bi-level geographic information systems database model to encourage the dissemination, use and production of geoinformation in developing countries. Int. Arch. Photogramm. Remote Sens. Spat. Inf. Sci. 2000, 33, 624-631.

137. Owen, K.K. Evaluating slum severity from remote sensing imagery. In Understanding Megacities with the Reconnaissance, Surveillance, and Intelligence Paradigm; Ehlschlaeger, C., Ed.; Topical Strategic Multi-Layer Assessment (SMA) and U.S. Army Engineer Research Development Center (ERDC) White Papers in Support of National Security Challenges: Vicksburg, MS, USA, 2014; pp. 67-75.

138. Thomson, C.N.; Hardin, P. Remote sensing/GIS integration to identify potential low-income housing sites. Cities 2000, 17, 97-109. [CrossRef]

139. Mishra, S.; Kuffer, M.; Martinez, J.; Pfeffer, K. An exploration of natural capital in the context of multiple deprivations. In Proceedings of the IEEE Joint Urban Remote Sensing Event (JURSE), Munich, Germany, 11-13 April 2011; pp. 157-160. 
140. Muriuki, G.; Seabrook, L.; McAlpine, C.; Jacobson, C.; Price, B.; Baxter, G. Land cover change under unplanned human settlements: A study of the Chyulu Hills squatters, Kenya. Landsc. Urban Plan. 2011, 99, 154-165. [CrossRef]

141. Zeilhofer, P.; Topanotti, V.P. GIS and ordination techniques for evaluation of environmental impacts in informal settlements: A case study from Cuiabá, central Brazil. Appl. Geogr. 2008, 28, 1-15. [CrossRef]

142. Sakijege, T.; Sartohadi, J.; Marfai, M.A.; Kassenga, G.R.; Kasala, S.E. Assessment of adaptation strategies to flooding: A comparative study between informal settlements of Keko Machungwa in Dar es Salaam, Tanzania and Sangkrah in Surakarta, Indonesia. Jàmbá J. Disaster Risk Stud. 2014, 6, 1-10. [CrossRef]

143. Ebert, A.; Kerle, N.; Stein, A. Urban social vulnerability assessment with physical proxies and spatial metrics derived from air- and spaceborne imagery and GIS data. Nat. Hazards 2009, 48, 275-294. [CrossRef]

144. Vuksanovic-Macura, Z. The mapping and enumeration of informal Roma settlements in Serbia. Environ. Urban. 2012, 24, 685-705. [CrossRef]

145. Karanja, I. An enumeration and mapping of informal settlements in Kisumu, Kenya, implemented by their inhabitants. Environ. Urban. 2010, 22, 217-239. [CrossRef]

146. Chitekwe-Biti, B.; Mudimu, P.; Nyama, G.M.; Jera, T. Developing an informal settlement upgrading protocol in Zimbabwe-The Epworth. Environ. Urban. 2012, 24, 131-148. [CrossRef]

147. Angeles, G.; Lance, P.; Barden-O'Fallon, J.; Islam, N.; Mahbub, A.Q.M.; Nazem, N.I. The 2005 census and mapping of slums in Bangladesh: Design, select results and application. Int. J. Health Geogr. 2009, 8, 19. [CrossRef] [PubMed]

148. Hassan, A.N.; Nogoumy, N.E.; Kassem, H.A. Characterization of landscape features associated with mosquito breeding in urban Cairo using remote sensing. Egypt. J. Remote Sens. Space Sci. 2013, 16, 63-69. [CrossRef]

149. Giada, S.; De Groeve, T.; Ehrlich, D.; Soille, P. Can satellite images provide useful information on refugee camps? Int. J. Remote Sens. 2003, 24, 4249-4250. [CrossRef]

150. Bramante, J.F.; Raju, D.K. Predicting the distribution of informal camps established by the displaced after a catastrophic disaster, Port-au-Prince, Haiti. Appl. Geogr. 2013, 40, 30-39. [CrossRef]

151. Adepoju, M.O.; Halilu, S.A.; SO, M.; Ozigis, S.M.; Idris, I.; Blessing, A.; Adeluyi, O.A. Geo-spatial technologies for Nigerian urban security and crime management-A study of Abuja crime hotspot mapping and analysis. In Proceedings of the ASPRS 2014 Annual Conference, Louisville, Kentucky, KY, USA, 23-28 March 2014; pp. 1-14.

152. Rahman, A.; Kumar, Y.; Fazal, S.; Bhaskaran, S. Urbanization and quality of urban environment using remote sensing and GIS techniques in East Delhi-India. J. Geogr. Inf. Syst. 2011, 3, 62-84. [CrossRef]

153. Ioannidis, C.; Psaltis, C.; Potsiou, C. Towards a strategy for control of suburban informal buildings through automatic change detection. Comput. Environ. Urban Syst. 2009, 33, 64-74. [CrossRef]

154. Risbud, N. Policies for tenure security in Delhi. In Holding Their Ground-Secure Land Tenure for the Urban Poor in Developing Countries; Durand-Lasserve, A., Royston, R., Eds.; Earthscan: London, UK, 2002; pp. 59-74.

155. Lemma, T.; Sliuzas, R.V.; Kuffer, M. Participatory approach to monitoring slum conditions: An example from Ethiopia. In Mapping for Change: Practice, Technologies and Communication: Proceedings of the International Conference on Participatory Spatial Information Management and Communication; Rambaldi, G., Corbett, J., Olson, R., McCall, M., Muchemi, J., Kyem, P., Weiner, D., Chambers, R., Eds.; IIED: London, UK, 2006; Volume 54, pp. 58-66.

156. Sartori, G.; Nembrini, G.; Stauffer, F. Monitoring of urban growth of informal settlements and population estimation from aerial photography and satellite imaging. Thirsty Cities in War-Occasional paper 2002.

157. Dewan, A.M.; Yamaguchi, Y. Using remote sensing and GIS to detect and monitor land use and land cover change in Dhaka Metropolitan of Bangladesh during 1960-2005. Environ. Monit. Assess. 2009, 150, $237-249$. [CrossRef] [PubMed]

158. Kohli, D.; Stein, A.; Sliuzas, R.V.; Kerle, N. Identifying and Classifying Slum Areas Using Remote Sensing; University of Twente Faculty of Geo-Information and Earth Observation (ITC): Enschede, The Netherlands, 2015.

159. Stokes, C.J. A theory of slums. Land Econ. 1962, 38, 187-197. [CrossRef]

160. Jankowska, M.M.; Weeks, J.R.; Engstrom, R. Do the most vulnerable people live in the worst slums? A spatial analysis of Accra, Ghana. Ann. GIS 2011, 17, 221-235.

161. Baud, I.; Sridharan, N.; Pfeffer, K. Mapping urban poverty for local governance in an Indian mega-city: The case of Delhi. Urban Stud. 2008, 45, 1385-1412. [CrossRef] 
162. Dare, P.M.; Fraser, C.S. Mapping informal settlements using high resolution satellite imagery. Int. J. Remote Sens. 2001, 22, 1399-1401. [CrossRef]

163. Abbott, J. Use of spatial data to support the integration of informal settlements into the formal city. Int. J. Appl. Earth Observ. Geoinf. 2001, 3, 267-277. [CrossRef]

164. Sliuzas, R.V. Opportunities for enhancing communication in settlement upgrading with geographic information technology-based support tools. Habitat Int. 2003, 27, 613-628. [CrossRef]

165. Stow, D.A.; Weeks, J.R.; Toure, S.; Coulter, L.L.; Lippitt, C.D.; Ashcroft, E. Urban vegetation cover and vegetation change in Accra, Ghana: Connection to housing quality. Prof. Geogr. 2013, 65, 451-465. [CrossRef] [PubMed]

166. Jacobsen, K.; Büyüksalih, G. Topographic mapping from space. In Proceedings of the 4th Workshop of EARSeL on Remote Sensing for Developing Countries/GISDECO, Istanbul, Turkey, 4-7 June 2008.

167. Jensen, J.R.; Cowen, D.C. Remote sensing of urban suburban infrastructure and socio-economic attributes. Photogramm. Eng. Remote Sens. 1999, 65, 611-622.

168. Pesaresi, M.; Ehrlich, D. A methodology to quantify built-up structures from optical VHR imagery. In Global Mapping of Human Settlement; Gamba, P., Herold, M., Eds.; CRC Press: Boca Raton, FL, USA, 2009; pp. $27-57$.

169. Tsai, Y.H.; Stow, D.; Weeks, J. Comparison of object-based image analysis approaches to mapping new buildings in Accra, Ghana using multi-temporal QuickBird satellite imagery. Remote Sens. 2011, 3, 2707. [CrossRef]

170. Kabir, S.; He, D.C.; Sanusi, M.A.; Hussin, W. Texture analysis of IKONOS satellite imagery for urban land use and land cover classification. Imaging Sci. J. 2010, 58, 163-170. [CrossRef]

171. Pacifici, F.; Chini, M.; Emery, W.J. A neural network approach using multi-scale textural metrics from very high-resolution panchromatic imagery for urban land-use classification. Remote Sens. Environ. 2009, 113, 1276-1292. [CrossRef]

172. Pesaresi, M.; Gerhardinger, A.; Kayitakire, F. A robust built-up area presence index by anisotropic rotation-invariant textural measure. IEEE J. Sel. Top. Appl. Earth Observ. Remote Sens. 2008, 1, 180-192. [CrossRef]

173. Engstrom, R.; Ashcroft, E.; Jewell, H.; Rain, D. Using remotely sensed data to map variability in health and wealth indicators in Accra, Ghana. In Proceedings of the IEEE Joint Urban Remote Sensing Event (JURSE), Munich, Germany, 11-13 April 2011; pp. 145-148.

174. Brito, P.L.; Quintanilha, J.A. A literature review, 2001-2008, of classification methods and inner urban characteristics identified in multispectral remote sensing images. In Proceedings of the 4th International Conference on Geographic Object Based Image Analysis, Rio de Janeiro, Brazil, 7-9 May 2012; pp. 586-591.

175. Pesaresi, M.; Kemper, T.; Gueguen, L.; Soille, P. Automatic information retrieval from meter and sub-meter resolution satellite image data in support to crisis management. In Proceedings of the IEEE Geoscience and Remote Sensing Symposium (IGARSS), Honolulu, HI, USA, 25-30 July 2010; pp. 1792-1795.

176. Estes, J.E.; Hajic, E.J.; Tinney, L.R. Fundamentals of image analysis: Analysis of visible and thermal infrared data. In Manual of Remote Sensing, 2nd ed.; Colwell, R.N., Ed.; American Society of Photogrammetry: Falls Church, VA, USA, 1983; pp. 987-1124.

177. Herold, M.; Liu, X.H.; Clarke, K.C. Spatial metrics and image texture for mapping urban land use. Photogramm. Eng. Remote Sens. 2003, 69, 991-1001. [CrossRef]

178. Mason, S.O.; Fraser, C.S. Image sources for informal settlement management. Photogramm. Rec. 1998, 16, 313-330. [CrossRef]

179. Blaschke, T.; Hay, G.J.; Kelly, M.; Lang, S.; Hofmann, P.; Addink, E.; Queiroz Feitosa, R.; van der Meer, F.; van der Werff, H.; van Coillie, F.; et al. Geographic object-based image analysis-Towards a new paradigm. ISPRS J. Photogramm. Remote Sens. 2014, 87, 180-191. [CrossRef] [PubMed]

180. Hofmann, P.; Strobl, J.; Blaschke, T. A method for adapting global image segmentation methods to images of different resolutions. Int. Arch. Photogramm. Remote Sens. Spat. Inf. Sci. 2008, 38, 1-7.

181. Esch, T.; Thiel, M.; Bock, M.; Roth, A.; Dech, S. Improvement of image segmentation accuracy based on multiscale optimization procedure. IEEE Geosci. Remote Sens. Lett. 2008, 5, 463-467. [CrossRef]

182. Drăguț, L.; Csillik, O.; Eisank, C.; Tiede, D. Automated parameterisation for multi-scale image segmentation on multiple layers. ISPRS J.Photogramm. Remote Sens. 2014, 88, 119-127. [CrossRef] [PubMed]

183. Kuffer, M.; Pfeffer, K.; Sliuzas, R.; Baud, I. Extraction of slum areas from VHR imagery using GLCM variance. IEEE J. Sel. Top. Appl. Earth Observ. Remote Sens. 2016, 9, 1830-1840. [CrossRef] 
184. Kundu, A. The Challenges of Making Indian Cities Slum-Free; LSE: London, UK, 2012.

185. Awrangjeb, M.; Ravanbakhsh, M.; Fraser, C.S. Automatic detection of residential buildings using LIDAR data and multispectral imagery. ISPRS J. Photogramm. Remote Sens. 2010, 65, 457-467. [CrossRef]

186. Gevaert, C.M.; Sliuzas, R.; Persello, C.; Vosselman, G. Opportunities for UAV mapping to support unplanned settlement upgrading. In Proceedings of GeoTech Rwanda 2015, Kigali, Rwanda, 18-20 November 2015.

187. Elvidge, C.D.; Baugh, K.E.; Howard, A.T.; Sutton, P.C.; Turtle, B.T.; Erwin, E.H. Can poverty rates be estimated using satellite data? In Proceedings of the IEEE Urban Remote Sensing Joint Event, Paris, France, 11-13 April 2007; pp. 1-4.

188. Wieland, M.; Pittore, M. Performance evaluation of machine learning algorithms for urban pattern recognition from multi-spectral satellite images. Remote Sens. 2014, 6, 2912-2939. [CrossRef]

189. Pratomo, J. Transferability of the Generic and Local Ontology of Slum in Multi-Temporal Imagery, Case Study: Jakarta; University of Twente Faculty of Geo-Information and Earth Observation (ITC): Enschede, The Netherlands, 2016.

190. Sandborn, A.; Engstrom, R.N. Determining the relationship between census data and spatial features derived from high-resolution imagery in Accra, Ghana. IEEE J. Sel. Top. Appl. Earth Observ. Remote Sens. 2016, 9, 1970-1977. [CrossRef]

191. Geiß, C.; Aravena Pelizari, P.; Marconcini, M.; Sengara, W.; Edwards, M.; Lakes, T.; Taubenböck, H. Estimation of seismic building structural types using multi-sensor remote sensing and machine learning techniques. ISPRS J. Photogramm. Remote Sens. 2015, 104, 175-188. [CrossRef]

(C) 2016 by the authors; licensee MDPI, Basel, Switzerland. This article is an open access article distributed under the terms and conditions of the Creative Commons Attribution (CC-BY) license (http:/ / creativecommons.org/licenses/by/4.0/). 